\title{
Silivrikapı Hadım İbrahim Paşa Camii'nin Plan Özellikleri ve Klasik Dönem Osmanlı Mimarlığı İçinde Benzer Örnekler Üzerine Bir Değerlendirme
}

\author{
Ayşe Denknalbant Çobanoğlu*
}

\begin{abstract}
Öz
Silivrikapı Hadım İbrahim Paşa Camii (1551) Mimar Sinan’ın Mimarbaşı olduğu dönemde inşa edilmiş tek minareli, kare planlı, kubbeli bir vezir yapısıdır. Cami, plan özellikleri dolayısıyla çeşitli araştırmalara konu olmuş, kubbesinin strüktürü açısından sekiz destekli camilerin öncüsü olarak değerlendirilmiştir. Yapının harim mekânında, duvarlardan çıııntılı olarak yerleştirilen payeler arasında sivri kemerli derin nişler oluşmuş, bu şekilde iç mekânda kısmen de olsa bir genişleme sağlanmıştır. Kalın tutulan duvar payeleri yukarı doğru devam etmekte ve köşelerdeki tromplara oturan kubbeyi taşımaktadır. Klasik Dönem Osmanlı Mimarlığı içinde, özellikle Mimar Sinan'ın mimarbaşı olduğu ve ekolünün devam ettiği yıllardaki gelişim incelendiğinde benzer plan özelliklerine ve kubbeyi taşıyan strüktüre sahip yapılar karşımıza çıkmaktadır. Silivrikapı Hadım İbrahim Paşa Camii'ndeki duvar payelerinin oluşturduğu sekizgen şemanın kubbeyi taşıma sistemi; Kilis Canbolat Paşa Camii, Tokat Ali Paşa Camii, Diyarbakır Behram Paşa Camii, Halep Dukakinzade (Adiliye) Camii ve Halep Behram Paşa Camii'nde de görülmektedir. Bu yapılarda duvara bitişen payeler üst örtüye kadar yükselmekte ve kubbeyi taşıyan strüktürü olușturmaktadır. Ancak alt sıra pencere hizasında bu plan tipine benzer gibi görülen ikinci bir grup yapı da ilk grup yapılarıyla karıștıılarak aynı özellikler gösterdiği zannedilmektedir. Oysa bu yapılarda duvarlara çıkıntılı olarak yerleştirilen payelerin iç mekânda oluşturduğu nişlerin üzerinde mahfil bulunmakta ve yukarıya doğru payeler devam etmemektedir. Dolayısı ile de esasında farklı plan ve iç mekân tesiri gösteren bu yapılarda (Fatih Bali Paşa Camii, Kayseri Hacı Doğan Camii ve Bağdat Abdülkadir Geylani Camii) kubbe, diğer örneklerde olduğu gibi ayakların da destek olduğu bir sistemle değil, pandantif ya da tromplarla duvarlar tarafindan taşınmaktadır. Böylece, plan üzerinde aynıymıs gibi görünen ancak kubbeyi tașıma strüktürleri açısından farklı olan iki varyasyon karșımıza çıkmaktadır. Bu plan tipinin XVI. yüzyılın ikinci yarısından itibaren Başkent İstanbul'da, Anadolu'da ve Osmanlı́nın hâkimiyetindeki eyalet merkezlerinde (Bağdat ve Halep) çeşitli kereler karşımıza çıkması, bir dönem uygulama olarak tercih edildiğini göstermektedir.
\end{abstract}

\author{
Anahtar Kelimeler \\ Osmanlı Mimarisi • 16. Yüzyıl • Silivrikapı Hadım İbrahim Paşa Camii • Sekiz Destekli Yapılar
}

An Evaluation of Characteristics of The Plan of Silivrikapi Hadim Ibrahim Pasha Mosque and Similar Examples in Ottoman Architecture

\begin{abstract}
Silivrikapı Hadım Ibrahim Pasha Mosque (1551) was built as a vizier structure by Mimar Sinan during his tenure as Chief Architect and has a single minaret and domes on a square layout plan. The mosque was characterized in several studies and concluded to be the pioneer of mosques with eight buttresses in terms of dome structure. The inner space features deep niches with pointed arches between protruding columns on the walls, which somewhat expand the space. The thick columns reach upwards to carry the dome placed on corner squinches. Buildings with similar layout plans and dome-bearing structures are observed in the development of Classical Ottoman Architecture, especially during the period of Mimar Sinan's influence as the Chief Architect. Dome-bearing system of the octagonal column layout in Silivrikapı Hadım Ibrahim Pasha Mosque is also seen in the Canbolat Pasha Mosque in Kilis, the Behram Pasha Mosque in Diyarbakır, Al Pasha Mosque in Tokat, Dukakinzade (Al-Adiliyah) Mosque in Aleppo and Behram Pasha (Behramiyah) Mosque in Aleppo. The columns, adjacent to the wall, ascend to the cover and form the dome-bearing structure. However, characteristics of a second group of structures are mistaken for the former group at the lower window level. These structures have platforms on interior niches on the protruding columns in the walls and the columns do not go up any further. Therefore, the domes of these structures (the Bali Pasha Mosque in Fatih, the Hacl Doğan Mosque in Kayseri, the Abdul-Qadir Gilani Mosque in Baghdad) are carried by pendentives or squinches instead of a system also supported by buttresses, seen in the aforementioned examples. Thus, there are two variations that appear to be similar on the layout plan but differ in dome-bearing structures. The fact that this layout type is observed at various places from the second half of the $16^{\text {th }}$ century onwards in capital city Istanbul, Anatolia and the centers of other Ottoman provinces (Baghdad and Aleppo) indicates that the type was preferred in practice for a period of time.
\end{abstract}

Keywords

Ottoman Architecture • 16. Century • Silivrikapı Hadım Ibrahim Pasha Mosque • Dome Structure with Eight Buttresses

* Sorumlu Yazar: Ayşe Denknalbant Çobanoğlu (Dr. Öğr. Üyesi), İstanbul Üniversitesi, Edebiyat Fakültesi, Sanat Tarihi Bölümü Türk ve İslam Sanatı Anabilim Dalı. Eposta: aysednb@istanbul.edu.tr, aysednb@yahoo.com

Atf: DENKNALBANT ÇOBANOĞLU, Ayşe, “Silivrikapı Hadım İbrahim Paşa Camii'nin Plan Özellikleri ve Klasik Dönem Osmanlı Mimarlığı İ̧̧inde Benzer Örnekler Üzerine Bir Değerlendirme", Art-Sanat, 11(Ocak 2019), s. 101-140.

https://doi.org/10.26650/artsanat.2019.11.0005 
Kubbe, Türk Mimarlığı içinde her dönemde önemli bir yere sahip olmuş, gelişim çizgisi içindeki uygulamalarla farklı çözümler ve örnekler ortaya konmuştur. 14. yüzyıldan itibaren İslam ve Selçuklu coğrafyasının örnekleri değerlendirilerek ve geliştirilerek ortaya çıkan Osmanlı mimarisinde, kare-prizmatik bir mekânın üzerini örten kubbeli bir düzen görülmektedir. Erken dönem Osmanlı camileri, kubbenin duvarlar tarafından taşındığı tek kubbeli ve kare planlı mekânlardır. Yapı hacimleri büyüdüğünde, üst örtüde kubbenin dişında tonoz ve küçük kubbeler kullanılmış (İznik Yeşil Camii/1378-79 gibi), 15. yüzyılın ortalarındaki hem maddi imkânların artışı hem de mimarideki teknikler, merkezi bir kubbeye önem veren ve yarım kubbelerin de eklenmesiyle zengin bir mimari meydana getirecek (Edirne Üç Şerefeli Camii/1438-47, Eski Fatih Camii/1463-71 gibi) çalışmalara ortam yaratmıştır. İbadet mekânının enine gelişmesi, merkezi kubbe isteğiyle birlikte değerlendirildiğinde her yöne gelişme ihtiyacı duyulmuş, bu durumda kubbe, taşıyıcısı olan beden duvarlarından kurtarılarak bazen dört, altı ya da sekiz dayanaklı bir sisteme oturmasıyla kubbenin mekâna hâkim konumda olması sağlanmıştır. 16. yüzyıl Osmanlı camilerinin hacimce büyük ve anıtsal olan örneklerinde harim mekânının üzerini örten kubbe, böyle bir taşıyıcı sisteme sahiptir' ${ }^{1}$.

Çok eski dönemlerden itibaren bilinen ve kullanılan sekizgen, daireden hareket edilerek varılmış poligonal bir formdur. Anadolu Türk mimarlığında ilk kullanılışına taşıyıcı sistem olarak değil, ancak plan olarak türbelerde rastlanmaktadır ve Selçuklularda pek çok örneği bulunmaktadır. Cami içinde taşıyıcı sistem olarak ilk kullanılış1 ise Manisa Ulu Camii (1376)'nde görülmektedir. Geleneksel ulu cami tipindeki bu yapının mihrap önü kubbesi sekizgen bir kasnağa oturmaktadır². Söz konusu kubbe, geleneksel mihrap önü kubbesi özellikleri göstermekte olup yan mekânlara açılmayı sağlamaktadır.

Kaynaklar, Manisa Ulu Camii'nden sonra sekizgen ayak sisteminin uygulandığ ilk yapı olarak Silivrikapı Hadım İbrahim Paşa Camii’ni işaret etmektedir. Ancak biraz daha ayrıntılı baktığımızda gelişim çizgisi içinde değerlendirilebilecek örnekleri çoğaltmak da belki mümkün olabilir. Örneğin; 15. yüzyılın ortalarında Akko-

1 Suut Kemal Yetkin, "Beylikler Devri Mimarisinin Klasik Osmanlı Sanatını Hazırlayışı", Ankara Üniversitesi İlahiyat Fakültesi Dergisi, C. 4, S. 3, Ankara 1955, s. 39-43; Selçuk Batur, "Osmanlı Camilerinde Sekizgen Ayak Şemasının Gelişmesi Üzerine”, Anadolu Sanatı Araştırmaları, I, İstanbul 1968, s. 140-141; Orhan Cezmi Tuncer, "Batıda Merkezi Kubbe ve Koca Sinan'ın Mekan Kavramı”, Sanat Tarihi Yıllığı, S .12, İstanbul 1983, s. 149-160; Selçuk Mülayim, "Kubbe", Türkiye Diyanet Vakfı İslam Ansiklopedisi, C. 26, Ankara 2002, s. 300-303.

2 Yetkin, a.g.e., s. 39-40; Batur, a.g.e., s. 139-141; Doğan Kuban, Osmanlı Dini Mimarisinde İç Mekan Teşekkülü (Rönesansla Bir Mukayese), İstanbul 1958, s. 50. Ayrıca ayrıntılı bilgi için bkz. Emel Esin, "Türk Kubbesi (Gök-Türklerden Selçuklulara Kadar)", Selçuklu Araştırmaları Dergisi, C. 3, Ankara 1971, s. 158-182; Ara Altun, Ortaçağ Türk Mimarisinin Anahatları İçin Bir Özet, İstanbul 1988, s. 71-80; Mustafa Cezar, "Türk Mimarisinde Kubbe”, Türkiyemiz, C. IX, S. 27, Ankara 1979, s. 32-38; Tarkan Okçuoğlu, Anadolu Selçuklu Mescitlerinde Kubbeye Geçiş Alanının Değerlendirilmesi, İstanbul Üniversitesi Sosyal Bilimler Enstitüsü, Sanat Tarihi Yüksek Lisans Tezi, İstanbul 1995; Hakkı Önkal, Anadolu Selçuklu Türbeleri, İstanbul 2015. 
yunlular döneminden Diyarbakır Parlı (Sefa) Camii'nde (1453-78) kubbeyi taşıyan bu sekizgen strüktür görülmektedir. Piramidal bir külahla örtülü olan kubbesi, henüz merkezi bir vurgu yapmaktan uzaktır³. Silivrikapı Hadım İbrahim Paşa Camii'nden sonra sekiz destekli taşıyıcı sistemiyle İstanbul Rüstem Paşa Camii (1561) karşımıza çıkmakta, bu taşıyıcı sistem en olgun formuna ise Mimar Sinan'ın 1575'te Edirne'de inşa ettiği Selimiye Camii'nde ulaşmaktadır. Böylece bu plan tipinin ana düşüncesi olan merkezi kubbeyle örtülü orta alanın yan mekânlarla bütünleşmesi ve görsel geçiş olgusunun sağlanması varılan son noktayı göstermektedir.

Silivrikapı Hadım İbrahim Paşa Camii tek kubbeyle örtülü kübik yapı düzeninden, kubbenin sekiz destekle taşınması sistemine geçişteki örnek olarak görülmekte ve yapı Türk Mimarlığı'nın gelişim süreci içinde, iç mekânda yer alan duvar payelerinin meydana getirdiği desteklerle, sekiz destekli camilerin öncüsü olarak kabul edilmektedir ${ }^{4}$.

Silivrikapı Hadım İbrahim Paşa Külliyesi, camisi, kurucusunun açık türbesi, bugün yıkılmış haldeki hamamı, mektebi ve çeşmesiyle birlikte ele alınmıştır. Yapının banisi olan Hadım lakabıyla meşhur İbrahim Paşa, Kanuni Sultan Süleyman devrinde Anadolu Beylerbeyi olmuş, vezir rütbesiyle İstanbul kaymakamlığı yapmış ve 1553 yıllarında ise üçüncü vezir olarak görev almıştı. Kendi adıyla anılan külliyesini, Mimar Sinan'ın Mimarbaşı olduğu dönemde, kitabesine göre 1551 yılında tamamlamıştır. 1648 ve 1754 depremlerinde büyük zarar gören yapı 1763-64 senelerinde onarılmıştır ${ }^{5}$. 1940’lı y1llarda da tamir edilen cami, özellikle 1999'daki son depremde de hasar görmüş ve restorasyon geçirmiştir.

3 Orhan Cezmi Tuncer, Diyarbakır Camileri Mukarnas Geometri Orantı, Diyarbakır 1996, s. 88.

4 Duran İşmen, Hadım İbrahim Paşa Külliyesi, İstanbul Üniversitesi Edebiyat Fakültesi Sanat Tarihi Bölümü Mezuniyet Tezi, İstanbul 1966, s. 10-15; Batur, a.g.e., s. 143; Oktay Aslanapa, Osmanlı Devri Mimarisi, İstanbul 1986, s. 209.

5 Tarkan Okçuoğlu, "Hadım İbrahim Paşa Camii", Dünden Bugüne İstanbul Ansiklopedisi, C. 3, İstanbul 1994, s. 490-491; Semavi Eyice, "İbrahim Paşa Külliyesi", Türkiye Diyanet Vakfı İslam Ansiklopedisi, C. 21, İstanbul 2000, s. 341; İ. Aydın Yüksel, Osmanlı Mimarisinde Kânûnî Sultan Süleyman Devri (926-974/1520-1566) İstanbul, C. VI, Ankara 2004, s. 241; Gülru Necipoğlu, Sinan Çağı Osmanlı İmparatorluğu'nda Mimarî Kültür, İstanbul 2013, s. 526; N. Çiçek Akçıl Harmankaya, Mimar Sinan Camilerinde Sembolizm, Mimar Sinan Güzel Sanatlar Üniversitesi, Sosyal Bilimler Enstitüsü, Türk İslam Sanatları Anabilim Dalı, Doktora Tezi, İstanbul 2017, s. 110; N. Çiçek Akçı1 Harmankaya, Mimar Sinan Camilerinde Sembolizm, İstanbul 2018, s. 111. 


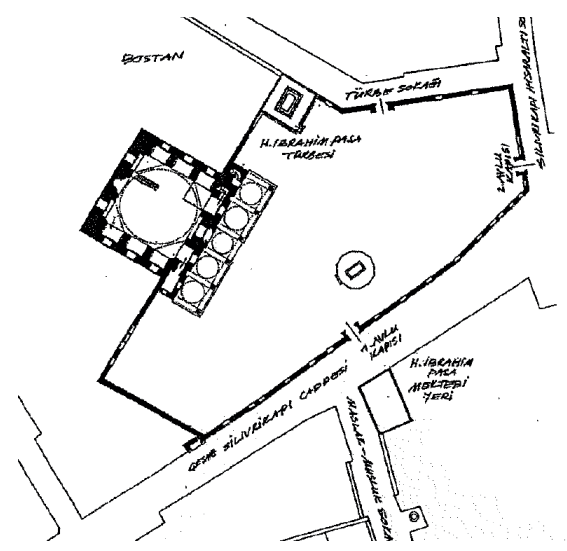

G. 1. Silivrikapı Hadım İbrahim Paşa Camii, Vaziyet Planı (A. Yüksel, 2004)

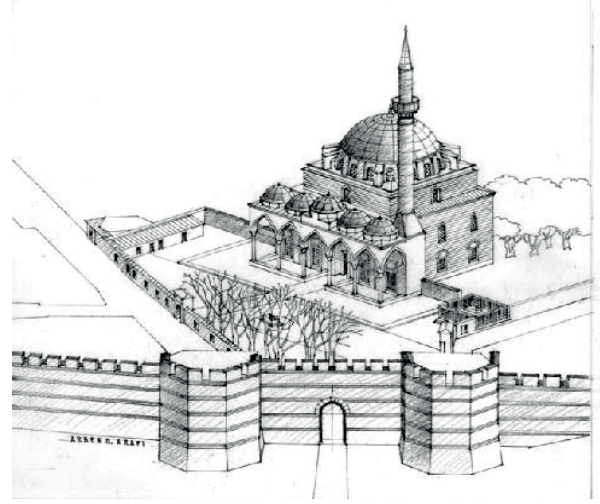

G. 2. Silivrikapı Hadım İbrahim Paşa Camii, Görünüşü (G. Necipoğlu, 2013)

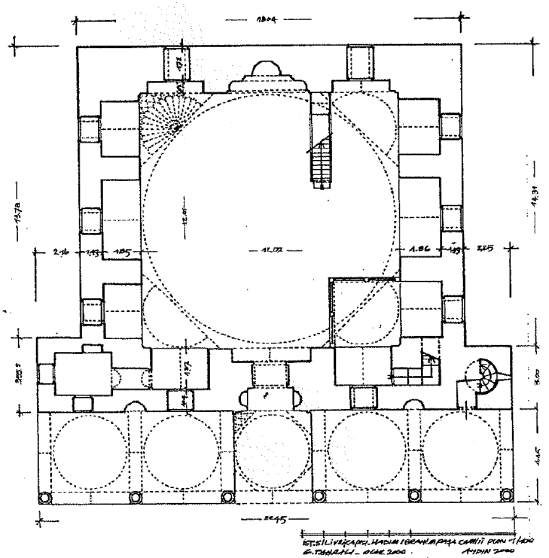

G. 3. Silivrikapı Hadım İbrahim Paşa Camii, Plan (A. Yüksel, 2004) 
Geniş bir avlu içinde konumlanan Hadım İbrahim Paşa Camii, kübik alt yapısı, pencereler açılmış kasnağın üzerinde yükselen kubbesi ve tek şerefeli minaresiyle küçük boyutlu bir yapıdır. Düzgün kesme köfeki taşı ve tuğlayla inşa edilmiştir. Yalnızca son cemaat yerine bakan cephesi kesme taştır (G. 4). Doğu ve batı cephelerde altta dikdörtgen formlu ve sivri alınlıklı üç pencereyle, üstte ise sivri alınlıklı üç revzenle dışa açılmaktadır. Bu düzenleme güney duvarında mihrabın denk geldiği akstaki pencerelere yer verilmemek suretiyle tekrar edilmiştir. Yapının önündeki beş gözlü son cemaat yerinin sivri kemerlerini baklavalı ve mukarnaslı başlıklara sahip sütunlar taşımaktadır. Yapıda önemli süsleme unsurları olarak, son cemaat yerindeki çiniler göze çarpmaktadır. Son cemaat yeri pencereleri üzerinde sivri alınlıklar ve madalyonlar şeklinde düzenlenen bu sır altı tekniğindeki mavi-beyaz çiniler, ayrıca lale ve karanfil motiflerinde görülen menekşe moru rengiyle de Şam İşi olarak tan1nan 16. yüzyıl İznik çinilerinin karakteristiğini göstermektedir. Aynı teknikteki başka bir çini alınlık da mihrap üzerinde yer almaktadır'.

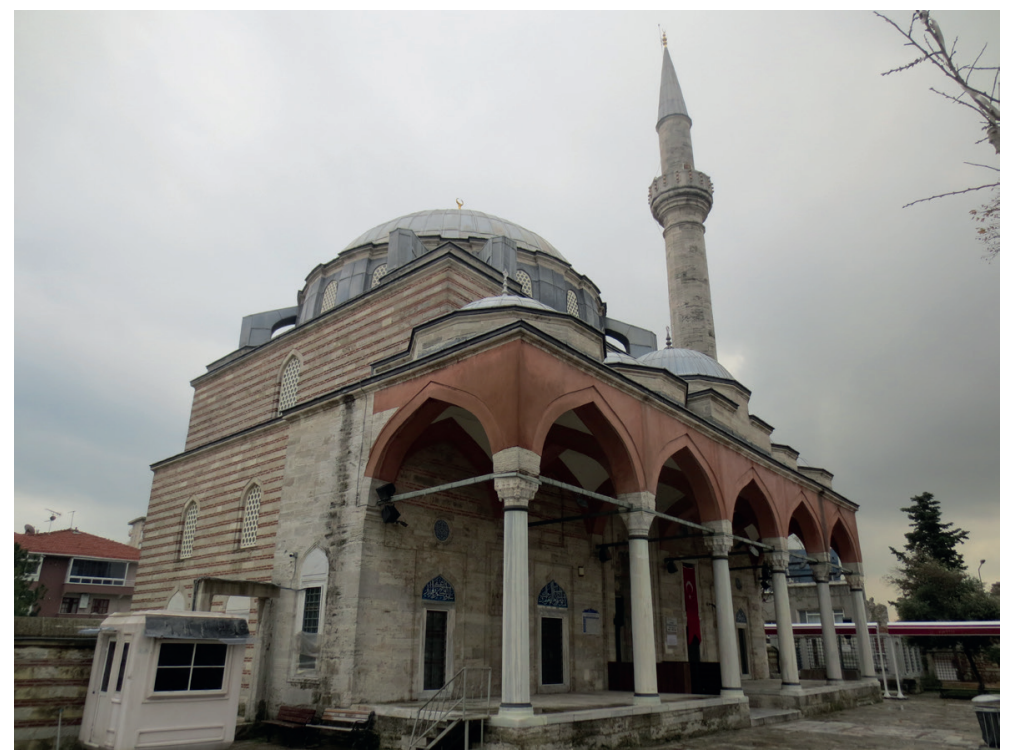

G. 4. Silivrikapı Hadım İbrahim Paşa Camii, Genel Görünüş (Ahmet Vefa Çobanoğlu, 2018)

Caminin üç yönde yanlara doğru genişleyen esas mekânının üzeri içleri istiridye kabuğu şeklinde düzenlenen tromplarla geçişi sağlanan tek kubbe ile örtülüdür (G. 1). İç mekânda dikkati çeken düzenleme, duvarlara bitişik kalın payeler arasında kalan derin niş bölümleridir (G. 5). Duvar payeleri arasındaki sivri kemerli derin nişler, ortadakiler daha geniş ve yüksek olmak üzere, doğu ve batı duvarlarında üçer, kuzey ve güney duvarlarında da ikişer tanedir (G. 6-8). Mihrap duvarındakilerin derinlikleri

6 Ayrıntılı bilgi için bkz. Şerare Yetkin, “İstanbul Silivrikapı’daki Hadım İbrahim Paşa Camii’nin Çinilerindeki Özellikler”, Sanat Tarihi Yıllığı, S. 13, İstanbul 1988, s. 199-211. 
diğerlerine oranla daha azdır. Kubbenin oturduğu sekizgen kasnağın destekleyicisi olarak değerlendirilen payeler üzerine mihrap yönünde yüzeysel mihraplar da yerleştirilmiştir. Caminin iç mekânında yer alan nişler iki katlı pencere düzenini içine almaktadır (G. 7). Nişlerin kemerleri trompların hemen hemen alt seviyesine kadar yükselmektedir. Kübik alt yapı bu seviyeye kadar algılanmakta olup trompları içine almamaktadır. Caminin alt yapısı yükseltilmiştir ve bunun da kara surlarının hemen içinde, Silivri Kapı arkasında yer alan yapının, sur dışından da rahatça algılanması için yapıldığını söylemek mümkündür (G. 2).

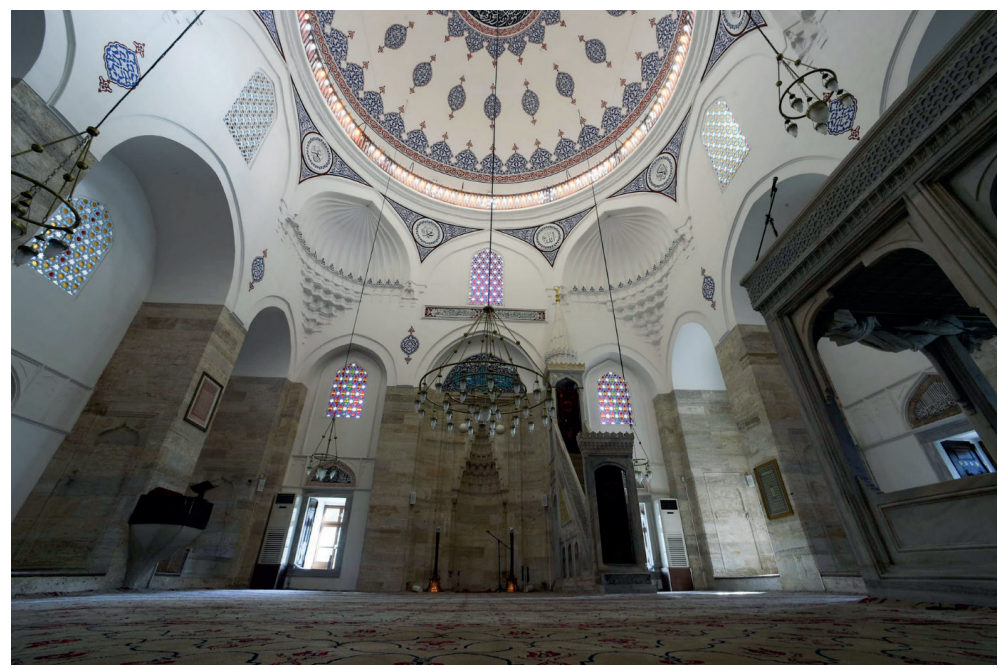

G. 5. Silivrikapı Hadım İbrahim Paşa, Harim Mekânı (wwww.turbelervecamiler.com)

S. Batur'un çalışmasında, 16. yüzyılın ortasında inşa edilen Hadım İbrahim Paşa Camii'nin planlanışı ve iç mekân düzeni üzerine çeşitli görüşler ve yorumlar yer almaktadır. Batur, gerek karenin içinde yer alan sekizgen şemanın belirtilmesi, gerekse de mekânın yanlara doğru genişletilmesi bakımından, yapının daha önceki örneklerden habersiz gibi planlandığını söylemektedir. Batur, bu durumun yapının küçüklüğüyle açıklanabileceğini belirtirken, Mimar Sinan’ın belki de bilinçli bir şekilde Hadım İbrahim Paşa Camii'nde uyguladığı bu yeni ve değişik çözüme kendi yetenekleriyle ulaşma çabasında olabileceğini düşünmektedir ${ }^{7}$. Bu yorum, mimarideki gelişmeleri, değişik çözümleri devamlı takip etmiş ve uygulamış bir toplumun sanatı için, özellikle de ortaya koyduğu ve uyguladığı planlarla önemli gelişmelere imza atan, sürekli bir devinim içinde olan Sinan gibi bir mimarı değerlendirmek için kaprisli ve kapalı bir fikir gibi görünmektedir. Mimar Sinan, bir yapıyı planlarken ve inşa safhalarında da, gerçekten de daha önce atılmış bir adımı görmezlikten gelebilir miydi, bilemiyoruz, ancak yorumumuz böyle olmadığı yönündedir. Batur ayrıca, İbrahim Paşa Camii’nde-

7 Batur, a.g.e., s. 156. 
ki çözüm şeklinin, daha önceki örneklere rağmen, sekizgen ayak sisteminin gelişmesinde ilk adım olarak değerlendirilebileceğini söylemektedir. Batur'a göre, İbrahim Paşa Camii, aslında ne taşıyıcı sisteme geçişin ne de mekânın yanlara doğru gelişmesinin ilk örneğidir; burada Mimar Sinan, kendinden önceki bütün gelişmeleri yok farz edip sekizgen taşıyııı strüktürü yeniden değerlendirmiş olmaktadır.

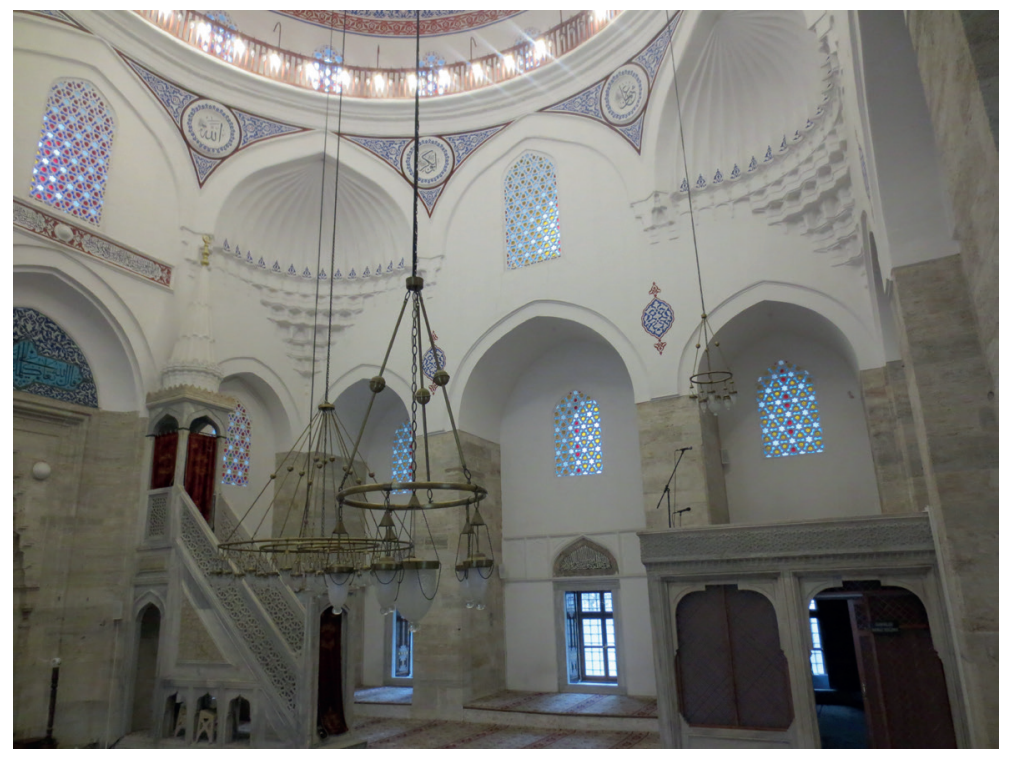

G. 6. Silivrikapı Hadım İbrahim Paşa Camii, Harim Mekânı (Ahmet Vefa Çobanoğlu, 2018)

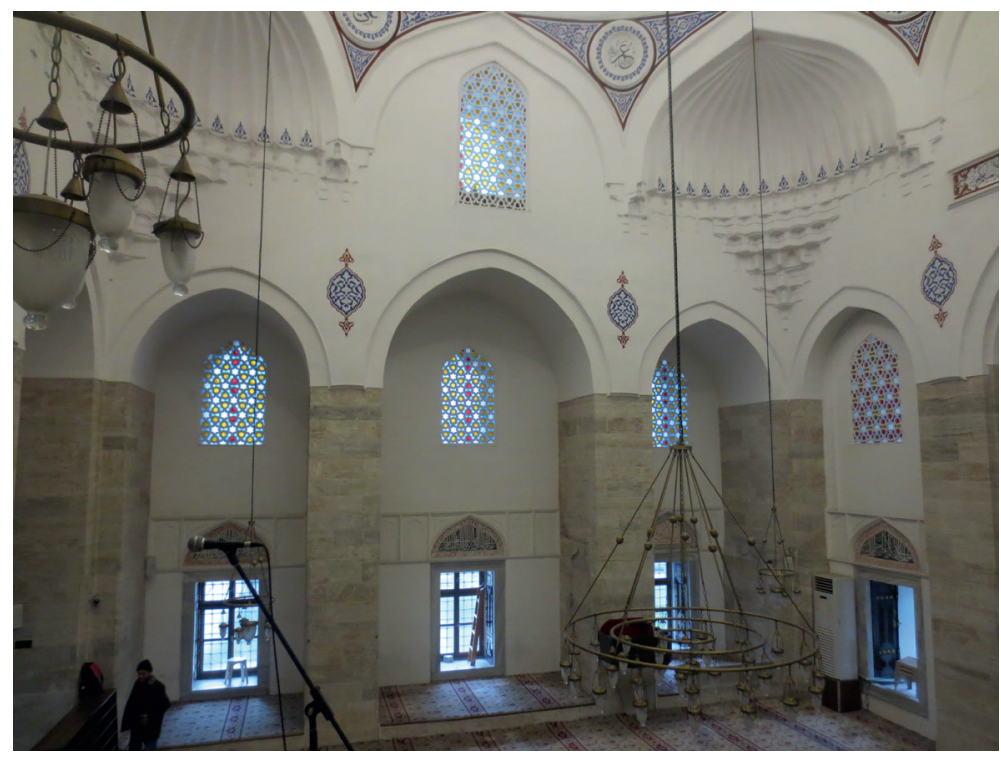

G. 7. Silivrikapı Hadım İbrahim Paşa Camii, Harim Mekanı (Ahmet Vefa Çobanoğlu, 2018)

8 Batur, a.e., s. 143. 


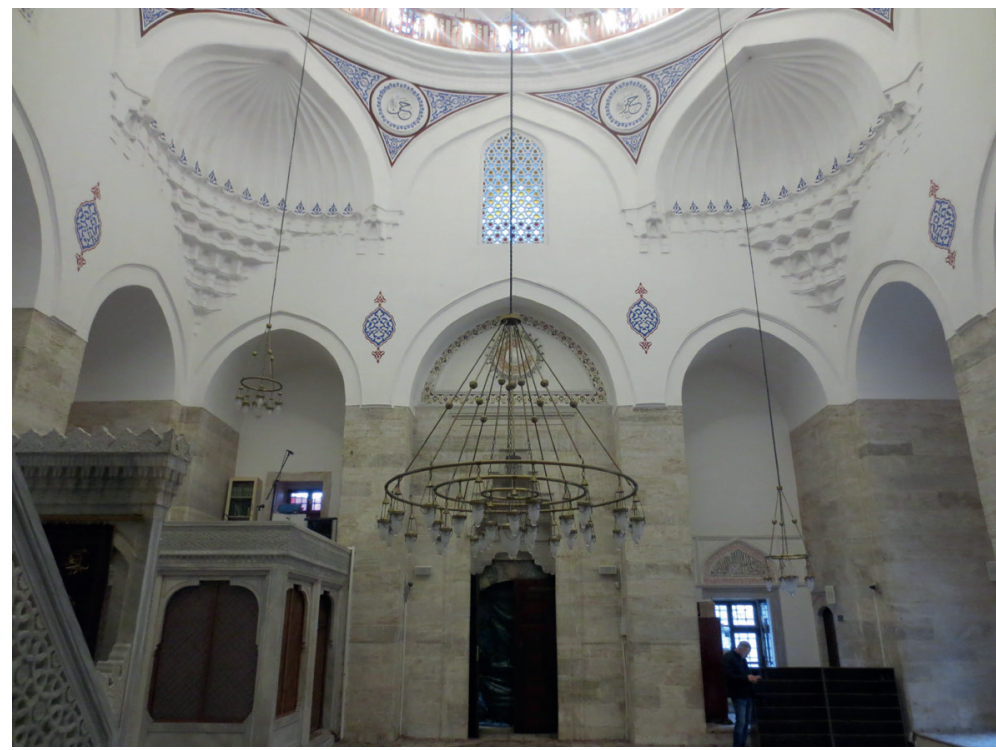

G.8. Silivrikapı Hadım İbrahim Paşa Camii, Kuzey Cephe (Ahmet Vefa Çobanoğlu, 2018)

Birçok kaynakta bazen karıştırılarak bazen de farklılıkları vurgulanmak üzere bu plan tipi içinde değerlendirilen Fatih Bali Paşa Camii'nin tarihi tartışmalı bir konu olmuştur. Caminin cümle kapısı üzerindeki kitabesine göre banisinin, Sultan II. Bayezid'in vezirlerinden İskender Paşa'nın kızı ve Bali Paşa'nın eşi Hüma Hatun olup 1504-1505 yıllarında inşa ettirilmiş olduğu düşünülmüştür. Başka kaynaklarda da Hüma Hatun'dan Sultan II. Bayezid'in kızı olarak bahsedilmektedir. Mimar Sinan'la ilgili tezkirelerde Bali Paşa Camii’nin Mimar Sinan'ın inşa ettiği yapılar arasında gösterilmesi de tarihlendirme açısından bir karışıklığga sebep vermektedir Bu durum büyük ölçüde kitabesinde tarih bulunmamasından ve yüzyıllar boyu kaynaklara değişik şekillerde aktarılan kitabesindeki bazı kelimelerin farklı okunmasından dolayı ebced hesabında da farklı tarihler çıkmasından kaynaklanmaktadır ${ }^{10}$.

9 İlk araştırmalarda, Sultan Beyazid'in kızı, Vezir Bali Paşa'nın hanımı Hüma Hatun tarafından 1504'te tamamlandığı ve Tezkerelerde Mimar Sinan'a mal edildiği için de daha sonraki yıllarda onun tarafından tamir edildiği düşünülmüştür. Aslanapa, a.g.e., s. 141; İhsan Erzi, Camilerimiz Ansiklopedisi, C. 1, İstanbul 1987, s. 99; Aydın Yüksel, Osmanlı Mimarisi: II. Bayezıd, Yavuz Selim Devri, İstanbul 1983, s. 178-183; Semavi Eyice, "İstanbul'da Bali Paşa Camii ve Mimar Sinan", Prof. Dr. Bekir Kütükoğlu'na Armağan, İstanbul 1991, s. 508.

10 Eyice, a.g.e., 1991, s. 511; Semavi Eyice, "Bali Paşa Camii”, Dünden Bugüne İstanbul Ansiklopedisi, C. 2, İstanbul 1994, s. 27-28. 


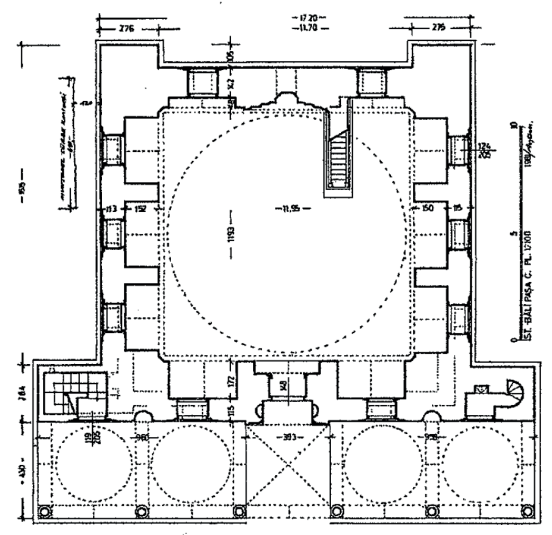

G. 9. Fatih Bali Paşa Camii, Plan (A. Yüksel, 2004)

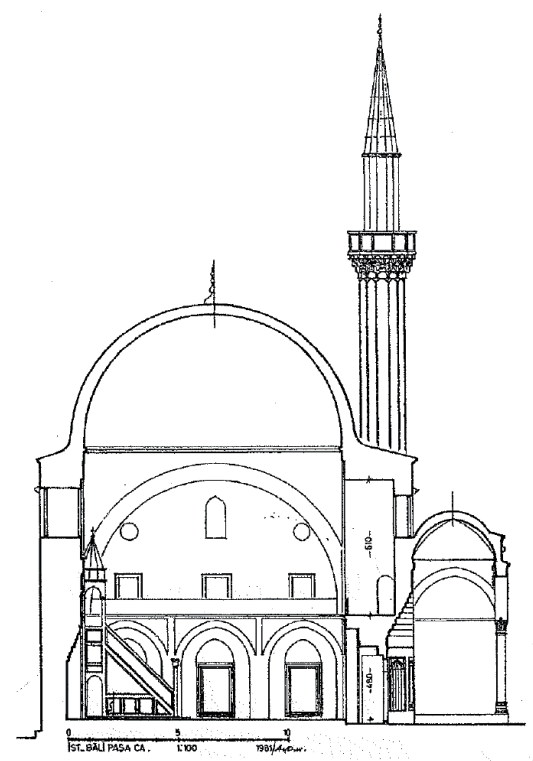

G. 10. Fatih Bali Paşa Camii, Kesit (A. Yüksel, 2004)

S. Eyice, yapının etraflı araştırması ve yorumu sonucu Mimar Sinan tarafından 1546 yılı civarında inşa edilmiş olduğunu söylemektedir. Ancak camiye ismini veren Bali Paşa'nın kimliği tam olarak tespit edilememiştir. Eyice, kitabede ismi geçen Hüma Hatun'un ise II. Bayezid'in kızlarından olan torunlarından biri olabileceğine ihtimal vermektedir. Daha sonra diğer araştırmacılar da S. Eyice'nin yapının tarihi konusundaki görüşüne katılmaktadırlar ${ }^{11}$. H. Kazan'ın sonraki yıllarda yapının vakfiyesiyle ilgili bir çalışması bulunmakta ve kitabede geçen isimlerle tarih karışıklığ konusuna açıklık

11 Eyice, a.g.e., 1991, s. 507-516; Eyice, a.g.e., 1994, s. 27-28; Yüksel, a.g.e., 2004, s. 59-62. 
getirmeye çalışmaktadır. Kazan, İstanbul Vakıfları Tahrir Defteri'ndeki kayda göre caminin 1546 yılında faaliyette olduğunu tespit etmiş, 1563 tarihli vakfiyesinin okunmas suretiyle yapının II. Bayezıd'in vezirlerinden İskender Paşa'nın kızı Hüma Hatun ve eşi Bali Paşa tarafından inşa ettirildiğini söylemiştir. Kazan, vakfiyenin tarihini göz önünde bulundurarak yapının 1563 civarında ya da hemen önceki bir zamanda inşa edilmiş olabileceği sonucuna varmaktadır ${ }^{12}$. G. Necipoğlu ise Hüma Hatun'un I. Selim'in 1515 'te idam ettirdiği vezir (damadı) İskender Paşa'nın kızı olduğunu söylemekte, 1546 tarihli vakfiyenin o dönemde banisi hala hayatta olduğu için tescil edilmemiş olduğundan bahsetmektedir. 1578-80 yıllarına ait tahrir defterinde ise caminin hem Hüma Hatun hem de Bali Paşa isimleriyle geçen vakfiyeleri mevcuttur. Necipoğlu, yapının tarihiyle ilgili olarak, caminin 1546'dan önce (belki de 1504-5'te) atılmış olan temeli üzerine Mimar Sinan'ın ya camiyi tamamlamış ya da kapsamlı bir onarım yapmış olabileceğinden bahsetmekte, ayrıca Bali Paşa Camii'nin planının Silivrikapı Hadım İbrahim Paşa Camii'nin planı için bir örnek teşkil edebileceğini düşünmektedir ${ }^{13}$. Aslında buradaki uzun tarih tartışması, Bali Paşa Camii'nin 1546 yıllarında inşa edildiği kabul edildiğinde plan özellikleri açısından, Silivrikapı Hadım İbrahim Paşa Camii'nden hemen önce görülen bir yapı olması açısından önem arz etmektedir.

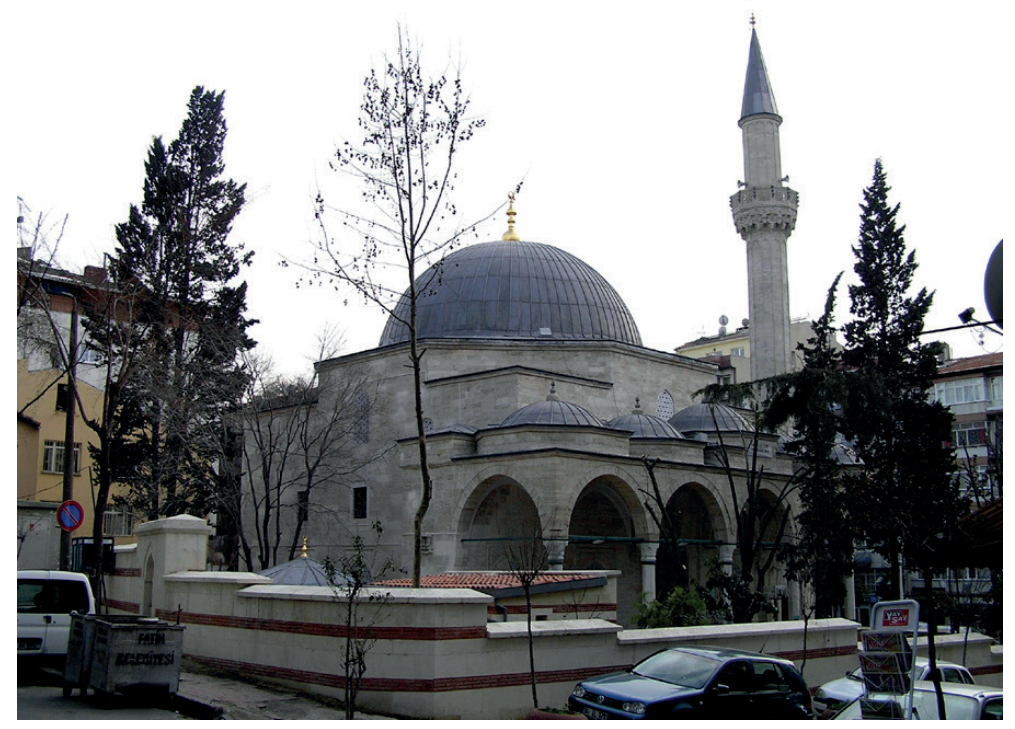

G. 11. Fatih Bali Paşa Camii (www.mimarsinan.gen.tr)

Düzgün kesme taşla inşa edilmiş olan Bali Paşa Camii kare planlı olup hariminin üzeri pandantiflerle geçişi sağlanmış tek kubbeyle örtülü bir yapıdır. Kuzeybatı yö-

12 Hilal Kazan, "İstanbul'da Bâli Paşa Vakfiyesi ve Yeni Bilgiler", Vakıflar Dergisi, S. 29, Ankara 2005, s. 55-75.

13 Necipoğlu, a.g.e., s. 528. 
nünde minaresi bulunmaktadır. Altı sütunla bölümlenmiş beş gözlü son cemaat yerinin XVIII. yüzyıl Barok üslubundaki sütun başlıkları, muhtemelen yapının 1766 depremi sonrasında geçirdiği onarımlara işaret etmektedir (G. 11). Cephelerde yer alan üç sıra pencerelerden alttaki iki sırası sivri kemerli ve mermer çerçevelidir. Üst sıradaki iki pencere ise yuvarlaktır. Kaynaklarda caminin fevkani olduğuna dair bilgi geçse de günümüzde böyle değildir. Meyilli bir arazide inşa edilen caminin altında bazı mekânlar olduğu kabul edilebilir. Yüzyıllar içinde geçirdiği yangınlar ve depremlerde çöken kubbesi ve son cemaat yeri kubbeleri, 1935 'te ve 1970 'li yıllarda onarılmıştır ${ }^{14}$.

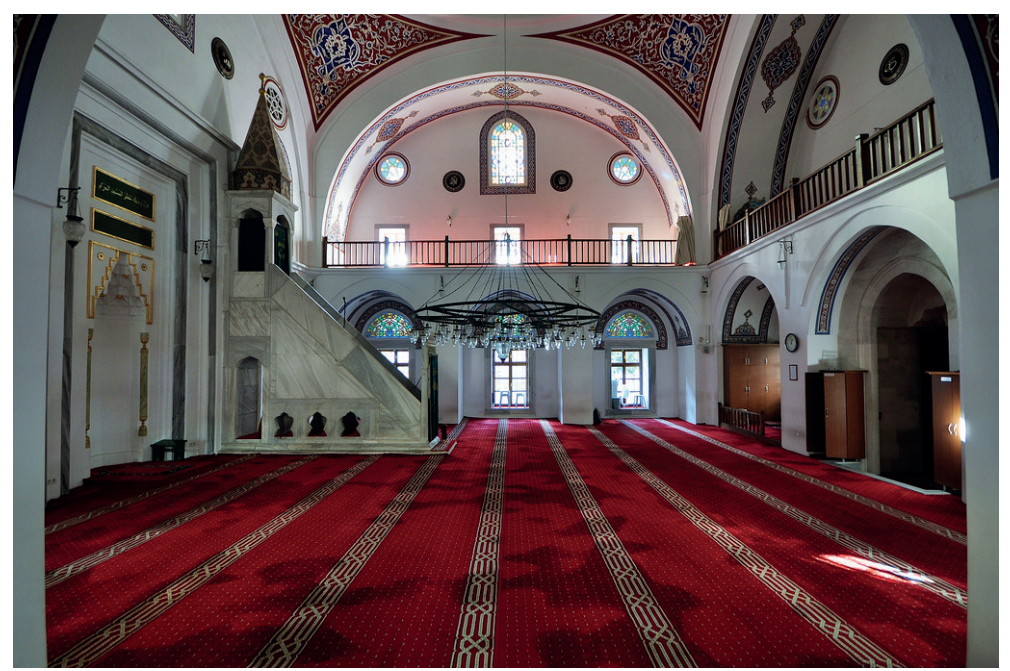

G. 12. Fatih Bali Paşa Camii, Harim Mekânı, (www.flickr.com)

Bali Paşa Camii’nin harim mekânı düzenlemesi de yukarıda ilk konu ettiğimiz Silivrikapı Hadım İbrahim Paşa Camii harimi gibi ilgi çekicidir (G. 9). Burada da mihrap cephesi hariç üç yönde duvarlarda payeler belirtilmiş, aralarında kalan bölümler de sivri kemerlerle bağlanmak suretiyle derin nişler şeklinde düzenlenmiştir. Nişlerin üzerinde de mekânı üç yönden saran mahfiller yer almaktadır. Kıble duvarında da köşeler dışarı taşkın payandalar şeklindedir (G. 12).

Silivrikapı Hadım İbrahim Paşa ve Bali Paşa Cami'lerini karşıllaştırarak ilerleyecek olursak, alt pencereler düzeyinde, Hadım İbrahim Paşa ile Bali Paşa Cami'lerinin planları arasında önemli bir fark yoktur. Fakat düşey planda farklılık bulunmaktadır. Hadım İbrahim Paşa Camii'nde duvar payeleri, sekizgen strüktüre destek verirken, Bali Paşa Camii'nde duvarların alt bölümünde yer alan payelerin işlevi, mahfilleri taşımaktan öteye geçmemektedir. Burada pandantif kullanıldığı için kubbenin yükü duvarlara değil yapının köşelerine aktarılmıştır ${ }^{15}$. Bali Paşa Camii için akla gelen bir

14 Eyice, a.g.e., 1991, s. 517-518; Yüksel, a.g.e., 2004, s. 62.

15 Aptullah Kuran, Mimar Sinan, Ankara 1987, s. 95. 
soru ise; mahfilleri taşımaktan başka bir görevleri olmayan bu ayakların neden bu kadar kalın inşa edilmiş olduğudur. Daha ince duvar parçaları ya da sütunlar da mahfilleri rahatıkla taşıyabilirdi. Harim mekânının yanlara ve kuzeye doğru genişlemesi sonucunu getiren bu planlamanın, payelerin taşıyıcı konumda olmadığı durumda bile bilinçli olarak uygulandığı düşünülebilir (G. 13, G. 14).

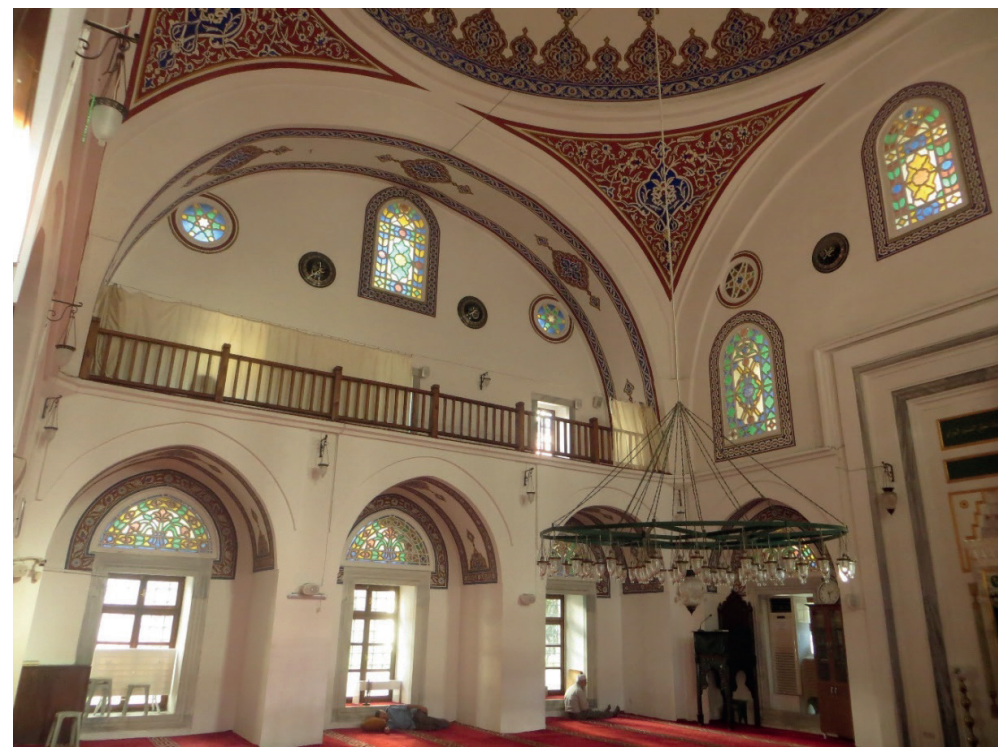

G. 13. Fatih Bali Paşa Camii, Harim Mekânı, Doğu Cephe (Ahmet Vefa Çobanoğlu, 2018)

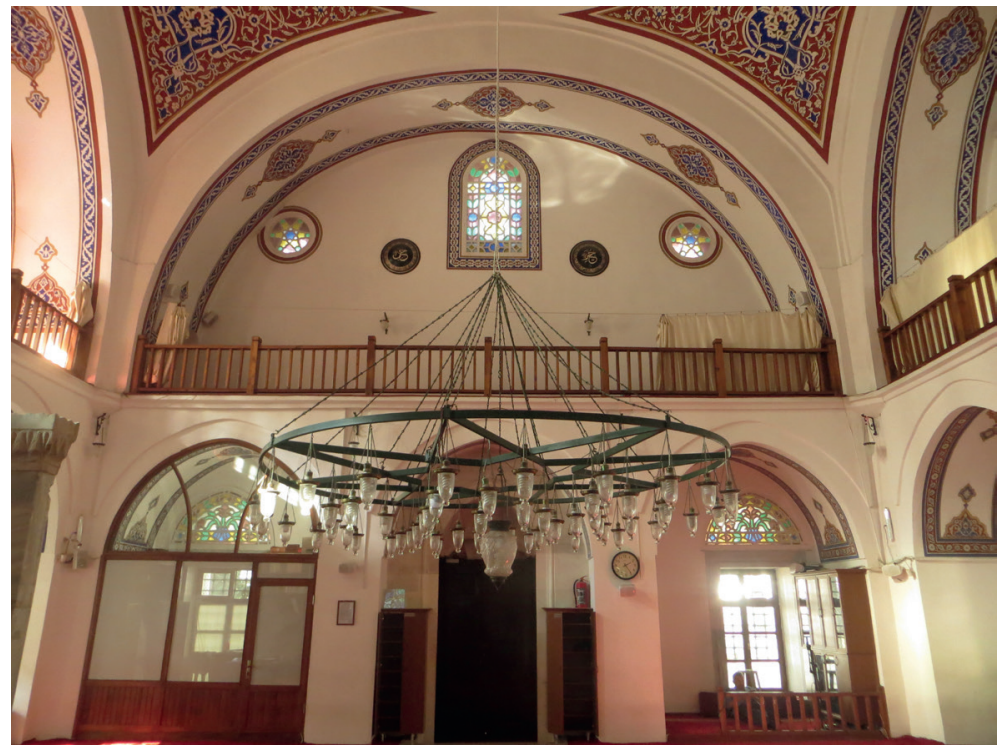

G. 14. Fatih Bali Paşa Camii, Kuzey Cephe (Ahmet Vefa Çobanoğlu, 2018) 
Silivrikapı Hadım İbrahim Paşa Camii'ne benzer plan özelliğine sahip olmasıyla dikkat çeken yapılardan Kilis Canbolat Tekke Camii, bir süre Kilis Sancakbeyliği görevinde bulunan Kasım Bey'in oğlu ve 1550-51 yıllarında Kilis Sancakbeyi olan Canbolat Paşa tarafindan 1553'te inşa ettirilmiştir. Canbolat Paşa, Tekke Camii'nin haziresindeki türbesinde gömülüdür ${ }^{16}$.

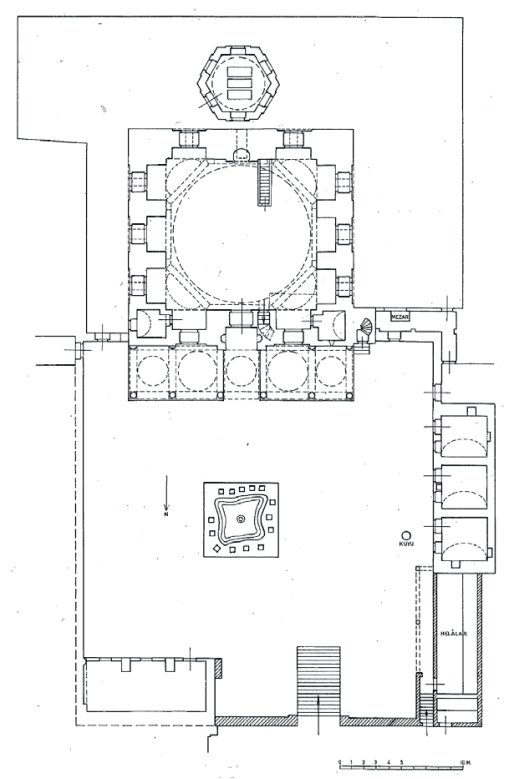

G. 15. Kilis Canbolat Paşa (Tekke) Camii, Plan (A. Dündar, 1999)

Yapı kesme taşla ve tek minareli inşa edilmiş olup tek kubbeyle örtülü kare planlı bir harime sahiptir. Yapının kuzey yönünde mukarnaslı sütun başlıklarına oturan sivri kemerli açıklıkların oluşturduğu beş gözlü bir son cemaat yeri, güneyinde ise türbe bulunmaktadır (G. 15, G. 16). Harim mekânı, iki katlı olarak düzenlemiş şekilde doğu ve batı cephelerde üçer, kuzey ve güney cephelerde ise ikişer adet pencereyle aydınlatılmaktadır. Pencerelerin iç ve dıştaki alınlıklarında, ayrıca son cemaat yeri pencere alınlıklarında lotus ve yuvarlak yapraklardan oluşan çiçek motifli çiniler kullanılmıştır. Beyaz zeminde mavi rengin hâkim olduğu çinilerde mor renk de dikkati çekmektedir ${ }^{17}$.

16 Abdülkadir Dündar, Kilis’teki Osmanlı Devri Mimari Eserleri, Ankara 1999, s. 17-18'de, kitabenin bulunması gereken yerde orijinal bir kitabe olmadığı, yakın zamana kadar boş duran bu yere üzerinde yapının adı ve 1552 olarak inşa tarihinin bulunduğu bir levha yerleştirildiği, yapının orijinal vakfiyesinin 1553 tarihli olmasının göz önünde bulundurulmasıyla da, yapının inşa tarihinin de 1553 olarak kabul edilebileceği belirtilmektedir. Ayrıca Canbolat Paşa için bkz. Metin Akis, "İ. Hakkı Konyalı Armağanına Katkı: Kilis Sancağında Canbolat Oğulları Ailesinin Yönetimi”, Şehirlerin Sevdalısı İbrahim Hakkı Konyalı Armağanı, Konya 2015, s. 392-393, 395, 397-398. İ. H. Konyalı Canbolat Paşa'nın 1571'deki Kıbrıs Seferi sırasında Magosa'da şehit olduğu ve buradaki türbeye defnedildiğini belirtmektedir. İ. H. Konyalı, Abideleri ve Kitabeleri ile Kilis Tarihi, İstanbul 1968, s. 460-461. Ancak belgelere göre Canbolat Paşa Kıbrıs Seferi'nden döndükten bir süre sonra Kilis’te vefat etmiş ve adına inşa ettirdiği camiinin haziresindeki türbeye defnedilmiştir. Akis, a.g.e., s. 397.

17 Gülümser Atasever, Kilis'de Türk Mimari Eserleri, İstanbul Üniversitesi Edebiyat Fakültesi Sanat Tarihi 


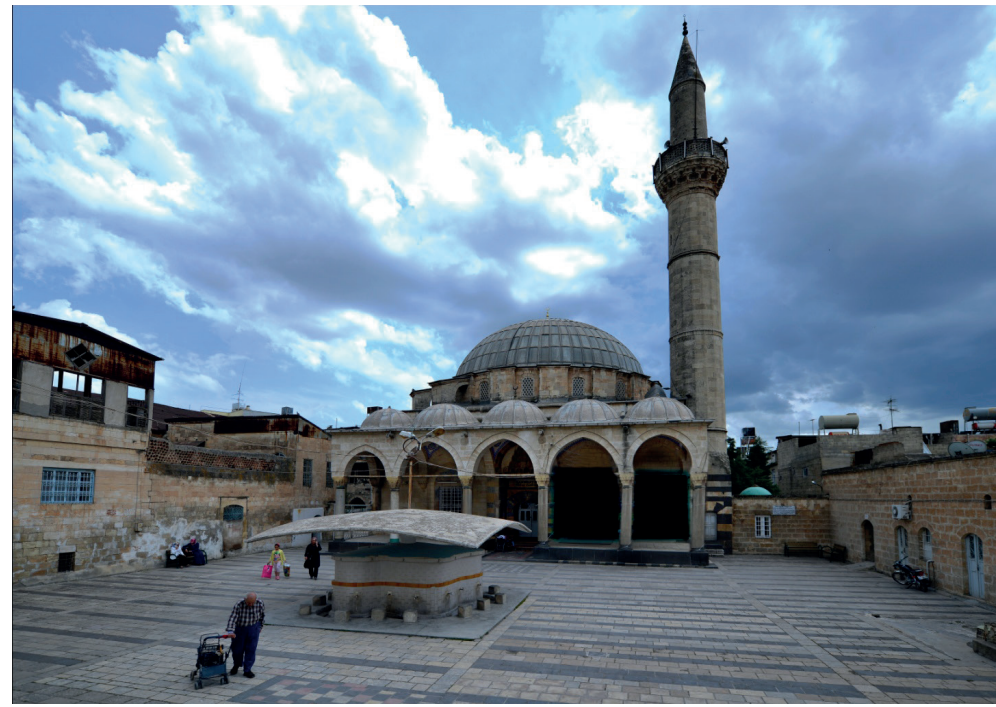

G. 16. Kilis Canbolat (Tekke) Camii (www.turab.org.tr)

Plan özelliklerine baktığımızda, kubbenin taşıma sistemi ve iç mekân organizasyonunun temelde Hadım İbrahim Paşa Camii'yle hemen hemen aynı olduğunu görmekteyiz. Ancak Canbolat Paşa Camii'nde mihrap duvarı Hadım İbrahim Paşa Camii'ndeki kadar ince değildir. Harim mekânında sekiz adet payenin her cephede ikişer tane yer almasıyla, payeler arasında kalan alanlar derin birer niş şeklinde düzenlenmiştir. Sivri kemerli bu nişler eşit genişlik ve yüksekliktedir. Kubbenin ağırlığı cephelerde görülen yüzeysel sivri kemerler ile bu payelere aktarılmaktadır. Kubbeye geçiş öğesi olarak da tromp kullanılmıştır. Ayrıca, kuzey duvarına, girişin sağında ve solundaki nişler içinden geçilerek ulaşılan birer köşe odasının konulmuş olması da planda dikkati çeken bir diğer özelliktir. Bu köşe odaları için, caminin adında geçen "tekke" kelimesiyle bir bağlantı kurulması ve buraların itikâf hücreleri olduğunu düşünmek mümkündür ${ }^{18}$ (G. 17).

Bölümü Türk Sanatı Kürsüsü Lisans Tezi, İstanbul 1969, s. 20-22; İnan, a.g.e., s. 8-11. Yapıda yer alan yazı ve bitkisel süslemeli çinilerin benzerleri Adana Ulu Camii türbesinde ve Halep Ulu Camii mihrap cephesinde de yer almaktadır. Osmanlı'nın Suriye'yi almasından sonra, Suriye atölyelerinde İznik ve İstanbul çinileri örnek alınarak üretim yapıldığı, morlu renkleriyle dikkat çeken bu çinilerin İznik etkisi taşımakla birlikte yerel üretimler olduklarından bahsedilmektedir. İnan, a.g.e., s. 13. Bu konudaki ayrıntılı bilgi için ayrıca bkz. J. Raby, "Diyarbakır, a Rival to İznik", İstanbuler Mittelungen, 27/28, Tübingen 1977-78, s. 439-459; Filiz Yenişehirlioğlu, "Les Revetement de Ceramiques Dans Les Edifices Ottomans de Diyarbakır au XVI e Siecle", Ars Turcica, Akten des VI. Inetrnalen Kongresses für Türksche Kunst, Münih 1987, s. 368393; Michael Meinecke, "Syrian Blue and White Tiles of the 9th/15th Century", Damaszener Mittellungen, 3, 1988, s. 203-214; Süreyya Eroğlu, "Kilis Tekke (Canpolat Paşa) Camisi'nin Mimarisi ve Süslemesi”, 21. Uluslararası Ortaçağ ve Türk Dönemi Kazıları ve Sanat Tarihi Araştırmaları Sempozyumu 25-27 Ekim 2017, Antalya 2017, Bildiri kitabı baskıda.

18 Yapının kuzey köşelerinde yer alan itikâf hücrelerinin benzeri kullanımı ile ilgili olarak ayrıca bkz. M. Baha Tanman, "Hekimoğlu Ali Paşa Camii’ne İlişkin Bazı Gözlemler", Aslanapa Armağanı, İstanbul 1996, s. 254-262. 


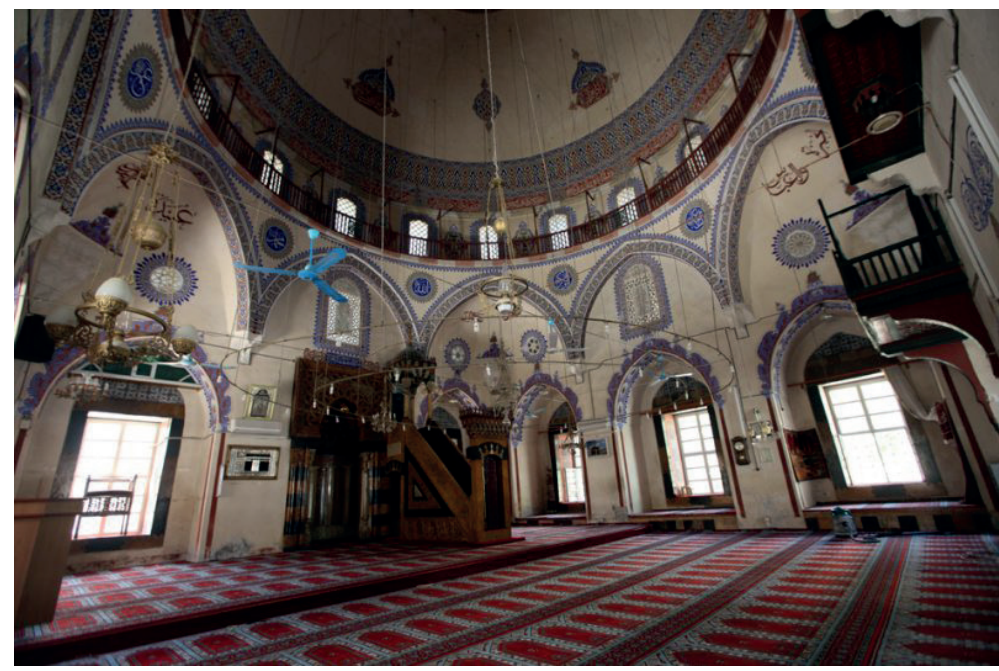

G. 17. Kilis Canbolat Paşa (Tekke) Camii, Harim Mekânı (www.ensonhaber.com)

Diyarbakır'ın 13. Osmanlı Valisi ve Beylerbeyi olan, Sokollu ailesinden Kara Şahin Mustafa Paşa'nın oğlu Behram Paşa, Urfa Sancakbeyliği, Gazze Sancakbeyliği ve Diyarbakır Beylerbeyliği (muhtemelen 1564-1568/69 arası) yapmış, 1578 yılında da Halep Beylerbeyliği'ne tayin edilmiştir ${ }^{19}$. Bazı tarihi kaynaklara göre ise, Behram Paşa, 1579'da ikinci kez Diyarbakır Beylerbeyliği'nde bulunmuş, 1580 yılı civarında ise Halep'e tayin edilmiştir ${ }^{20}$. Paşa vefat ettiğinde, Halep'te aynı isimle anılan camisinin güneyindeki türbeye defnedilmiştir ${ }^{21}$. Behram Paşa tarafından 1564-1572/73 yılları arasında yaptırılan Diyarbakır Behram Paşa Camii de, plan üzerinde ilk örneğimizi desteklemektedir ${ }^{22}$. Tamamen kesme taştan inşa edilmiş tek kubbeli ve tek minareli bir yapıdır. Caminin beden duvarlarından dışa taşkın olan beş gözlü son cemaat yerinin cephesi krem rengi ve siyah taşlarla alternatif olarak örülmüştür. Son cemaat yerini düz çatılı bir revak çevrelemektedir (G. 18, G. 19).

19 Şevket Beysanoğlu, Anıtları ve Kitabeleri ile Diyarbakır Tarihi Akkoyunlular'dan Cumhuriyet'e Kadar, C. 2, Ankara 1996, s. 573; Meryem Kaçan Doğan, "XVI. Yüzyılda Halep’te Bir Osmanlı Vakfi: Behram Paşa Külliyesi”, Türk Kültürü İncelemeleri Dergisi, İstanbul 2010, s. 2-3.

20 Necipoğlu, a.g.e., s. 623.

21 Necipoğlu, a.e., s. 623.

22 Aslanapa, a.g.e., s. 238; B. Günkut, Diyarbekir Tarihi, Diyarbakır 1937, s. 121; Beysanoğlu, a.g.e., s. 573; Necipoğlu, a.g.e., s. 623. 

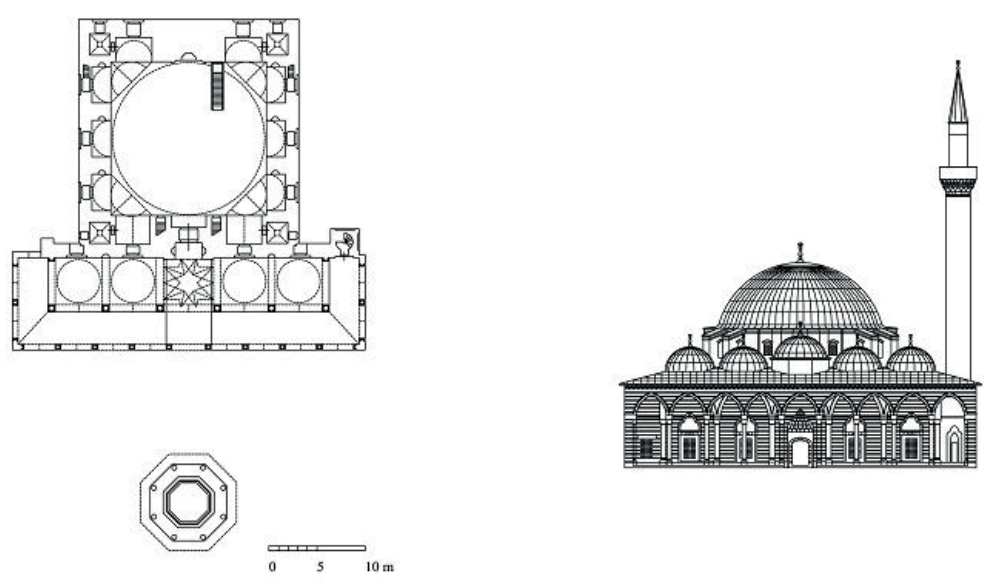

G. 18. Diyarbakır Behram Paşa Camii Plan, Görünüş (Necipoğlu, 2013, www.archnet.com )

Kare planlı harimi örten kubbe, tromplarla geçişi sağlanan on altıgen bir kasnak üzerine oturmaktadır. Harimin doğu ve batı yönlerinde duvarlardan çıkıntılı olarak yerleştirilen payelerle oluşturulan üçer derin niş yer alır. Bu nişler güney ve kuzey duvarlarında mihrap ve taçkapı düzenlemesiyle ikiye düşmektedir ${ }^{23}$. Silivrikapı Hadım İbrahim Paşa Camii’nden farklı olarak payeler yapının dört duvarına konmuş, böylece mihrap cephesinde de nişler oluşturulmuştur ${ }^{24}$. Bu yapıda, Fatih Bali Paşa Camii'nde gördüğümüz nişlerin üzerini bütünüyle kaplayan mahfilden ziyade, sadece ortadaki nişin üzerine denk gelecek şekilde mahfil yerleştirilmiştir. Bu suretle, mahfil burada payeleri bölmemekte, böylece payelerin taşıyıcı özellikleri devam etmektedir. Tromp kemerleri ve mahfil kemerleri de mukarnaslı bir düzenlemeyle duvar payelerine oturmaktadır (G. 17). Ayrıca nişlerin güney yönlerine birer de mihrap yerleştirilmiştir. Harimin alt duvarları da bütünüyle saz yaprakları, hatayi palmetler ve rozetlerden oluşan çinilerle kaplıdır ${ }^{25}$ (G. 15).

23 Orhan Czemi Tuncer, Diyarbakır Camileri, Diyarbakır 1996, s. 145.

24 Kuran, a.g.e., s. 96.

25 Necipoğlu, a.g.e., s. 625; Raby, a.g.e., s. 435-459; Yenişehirlioğlu, a.g.e., s. 368-393; Meinecke, a.g.e., s. 203-214. 


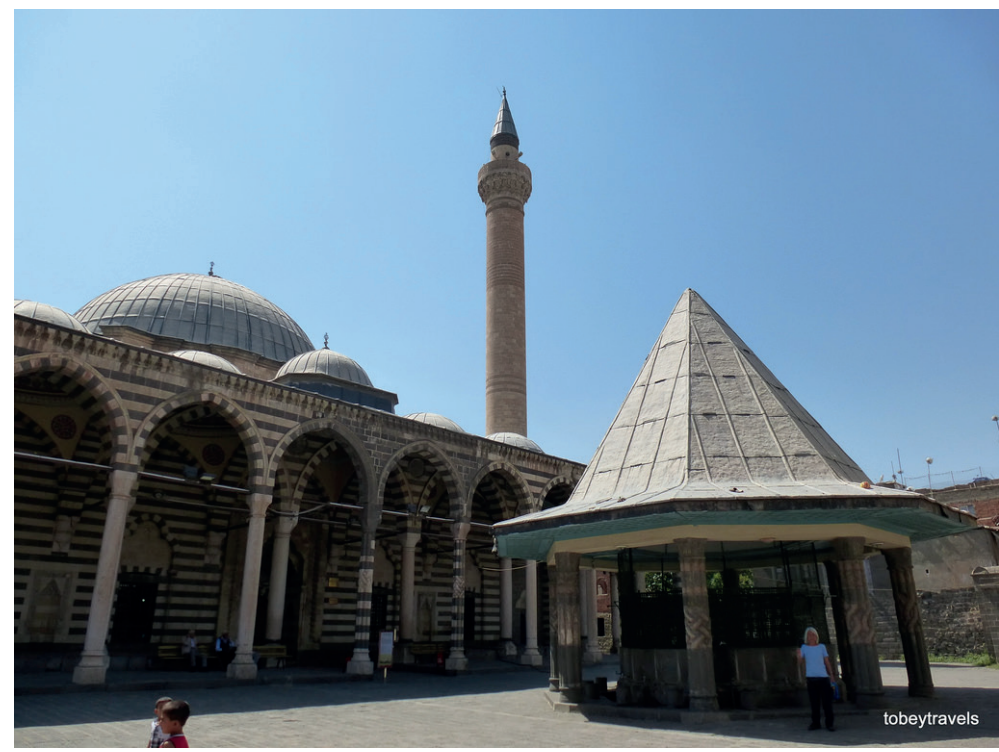

G. 19. Diyarbakır, Behram Paşa Camii (www.flickr.com)

Silivrikapı' da kübik alt yapı trompların alt seviyesine kadar çıkarken Behram Paşa Camii'nde ise bu kübik alt yapı trompları da içine almaktadır. Behram Paşa Camii’nde, doğu ve batı duvarlarında, ortadaki nişlerin üzerine denk gelecek şekilde ve bu nişlerin derinliğince mahfiller yerleştirildiğini görmekteyiz (G. 20-22). Hadım İbrahim Paşa Camii'nde bu bölümler sivri kemerlerle bağlanmıştır ve duvarın düzenlenişi de fark1ıdır. Behram Paşa Camii'nde dikkatimizi çeken diğer bir özellik de, Canbolat Tekke Camii'nde sadece kuzey duvarında gördüğümüz köşe odalarının, burada güney duvarına da iki katlı olarak yerleştirilmiş olmasıdır. Bu köşe odaları, muhtemelen tasavvufi ibadetler için ayrılan mekânlar olmalıdır ${ }^{26}$. Bu odalarla, kubbe yükünün duvarlara yayıldığ 1 tromplu sistemde, köşenin duvarları kenetlemenin ötesinde bir işlevi olmadığ da ifade edilmiş olmaktadır ${ }^{27}$. Mihrap duvarı da şimdiye kadar gördügüümüz örnekler içinde en kalın olanıdır. Bu güney duvarında oluşan nişlerin derinliği de buraya odaların yerleştirilmesinden kaynaklanmaktadır. Mihrap duvarındaki bu nişler sadece köşe odalarına geçiş için ya da harim mekânı içinde simetrik bir düzenleme yapma amacıyla plana dâhil edilmiş olmalıdırlar (G. 21). Bu bölümler mihrap cephesinde yer aldığı için imamın önünde kalmaktadır, cemaat de buralarda namaz kılamayacağına göre namaz vakitleri dışında kullanılan mekânlar oldukları düşünülebilir.

Hakkında epey araştırma bulunan bu yapı için kaynaklarda çeşitli yorumlar da karşımıza çıkmaktadır. M. Sözen, ilk bakışta tek kubbeli basit bir yapı gibi görünen

26 Tanman, a.g.e, s. 254-262.

27 Kuran, a.g.e., s. 96. 
cami için, tek kubbeli bir harim mekânının nasıl zenginleştirileceği konusunda güzel bir örnek olduğundan bahsetmektedir. Caminin ilk bakışta biraz basık görünmesini aksayan bir yön olarak değerlendirirken, duvar payelerinden elde edilen kemerli nişler ve bunların üzerindeki mahfillerin bu basıklığı giderdiğini belirtmektedir ${ }^{28}$.

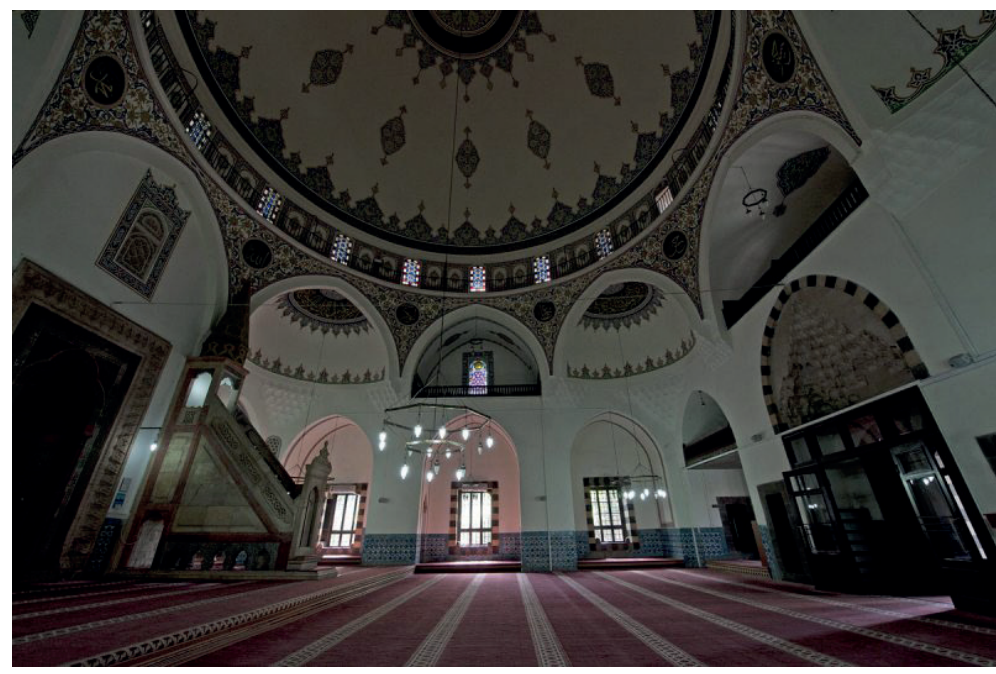

G. 20. Diyarbakır Behram Paşa Camii, Harim Mekânı (www.Pbase.com)

O. C. Tuncer ise çalışmasında Behram Paşa Camii planını Sinan'ın daha önce İstanbul'da iki yapıda denediğinden bahsetmekte, ilk örnek olarak Fatih Bali Paşa Camii'ni ve ikinci örnek olarak da Silivrikapı Hadım İbrahim Paşa Camii'ni vermektedir. Bu iki plan için, arazi özelliklerinden doğan bazı farklılıklar dışında hemen hemen birbirlerinin eşi olduklarını söylemektedir. Ancak Tuncer' in Bali Paşa, Hadım İbrahim Paşa ve Behram Paşa Camii'lerini aynı plan üzerinde değerlendirmesi doğru gözükmemektedir. 


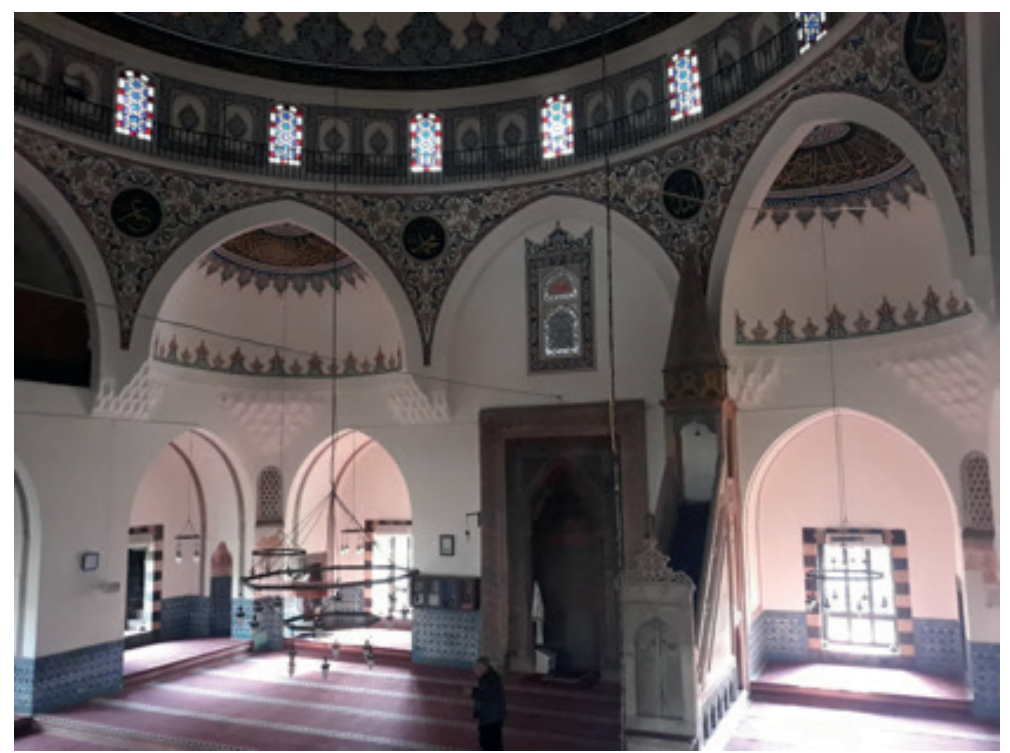

G. 21. Diyarbakır Behram Paşa Camii, Mihrap Cephesi (Selahattin Özeren, Mahfuz Ateş, 2018)

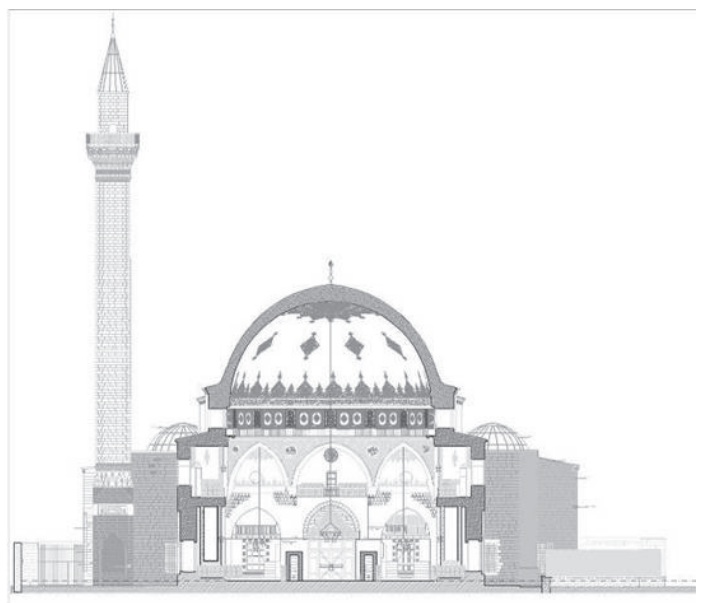

G. 22. Diyarbakır Behram Paşa Camii, Kesit (www.mimomimarlık.com)

Zira Bali Paşa Camii, her ne kadar temel planında bu yapılarla aynı olsa da üst örtüyü taşıma strüktürü farklıdır. Yapıyı doğu, batı ve kuzey yönlerde saran mahfiller, payelerin üst örtüyle olan ilişkisini kesmekte ve kubbe dört köşedeki pandantiflerle taşınmaktadır. Tuncer, bunlardan başka, Sinan'ın Behram Paşa Camii’nde niye bu planı uyguladığı üzerinde de durmaktadır. Tuncer'e göre, bu yapının yapıldığ1 tarihlerde Mimar Sinan İstanbul'da Mihrimah Sultan ve Haseki Sultan'ın yapılarıyla ilgilenmektedir. Bali Paşa, Mihrimah ve Haseki Sultanlardan sonraki sıralardadır ve 
Mimar Sinan bu nedenle de sade ve ufak bir yapı planına ihtiyaç duymuş olabilir. Bali Paşa Camii'nin inşa tarihi olarak 1546 civarı kabul edildiğinde, Mimar Sinan aynı planı bazı değişikliklerle 1551'de İbrahim Paşa'nın Camii'nde de uygulamıştır. Behram Paşa ondan bir yapı istediğinde Sinan'ın işleri muhtemelen aynı yoğunlukta devam etmektedir ve daha önce Hadım İbrahim Paşa ve Bali Paşa Camii'lerinde denediği planı biraz daha farklı özelliklerle düzenleyerek Diyarbakır'a göndermiş olabilir ${ }^{29}$. Tuncer'in yukarıda değindiğimiz yorumları, Mimar Sinan'ın mevcut bir planı birkaç kere kullanmasına sebep olarak gösterilmekle beraber, esasında Sinan'ın bu planı iç mekân kuruluşundaki hangi soruyu çözümlemek ya da farklı bir iç mekân kurgusuna varmak adına yaptığı yolundaki sorulara cevap verememektedir.

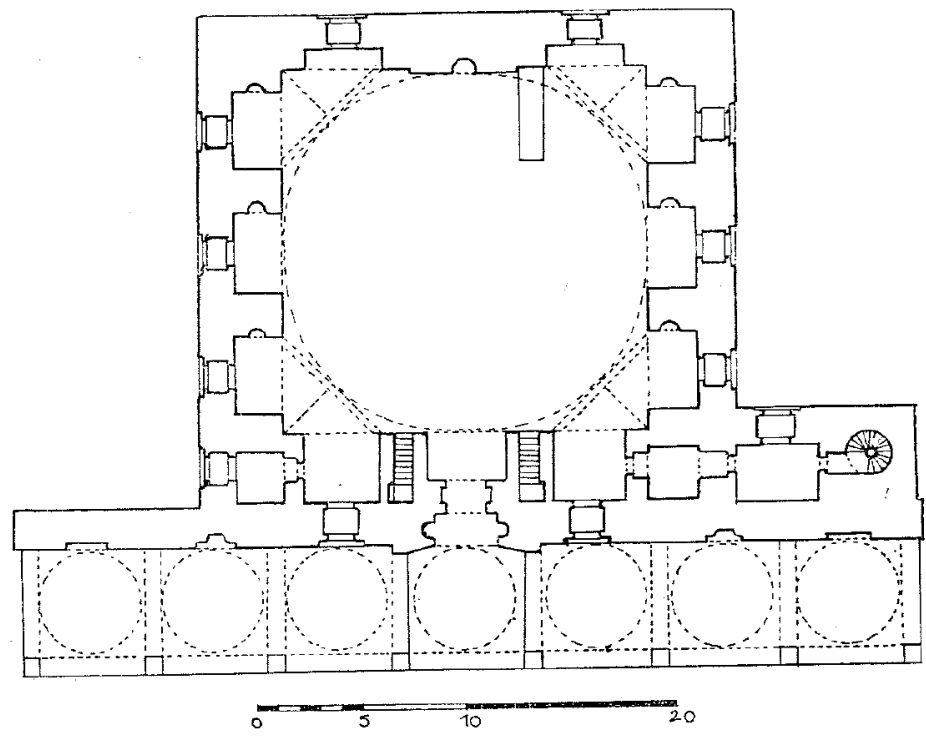

G. 23. Tokat Ali Paşa Camii, Plan (O. Uysal, 1987) 


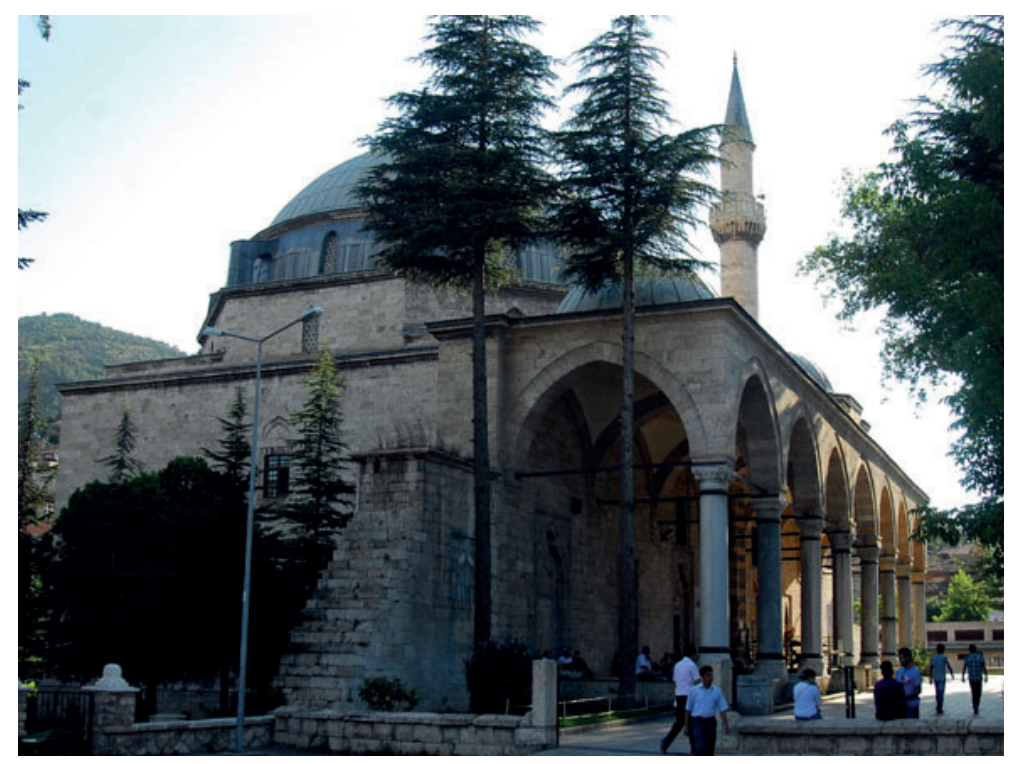

G. 24. Tokat Ali Paşa Camii (www.mustafacambaz.com)

Tokat Ali Paşa Camii de plan özellikleri olarak bahsettiğimiz yapılara yakın özellikler göstermektedir ${ }^{30}$. Caminin kuzeyinde yer alan türbede medfun olan Ali Paşa, mezar taşındaki kitabeye göre 1572-73 senesinde vefat etmiştir. Caminin, mezar taŞındaki tarih ve yapının mimari özellikleri açısından XVI. yüzyılın üçüncü çeyreğinde inşa edildiği ileri sürülmektedir ${ }^{31}$. S. Eyice, yerel bir kaynakta yayımlanmış bilgilere göre yapının 1572-73 tarihli Arapça bir vakfiyesi bulunduğunu, caminin kurucusunun da Ali Paşa olarak belirtildiğinden bahsetmektedir. Ancak, bazı ihtimaller ileri sürülse de yapının banisi olan Ali Paşa'nın kimliği tespit edilememiştir ${ }^{32}$. Ali Paşa Camii, kalın duvarlar üzerinde diştan sekizgen, içten on altıgen bir kasnağa oturan ve tromplarla geçişi sağlanan tek kubbeli bir yapıdır. Kuzey cephesinde sekiz sütunun taşıdığı sivri kemerlerle yedi gözlü bir son cemaat yerine sahiptir (G. 23, G. 24).

Caminin harim mekânının doğu ve batı duvarlarına yerleştirilen payelerle oluşturulan ve harim mekânına büyük kemerlerle açılan üçer tane, kuzey duvarında ise iki tane derin niş bu yapıda da dikkati çekmektedir (G. 25, G. 26). Diyarbakır Behram Paşa Camii'de olduğu gibi, ortadaki nişlerin üzerine gelecek şekilde, sivri kemer

30 Yalçın Yazıcı, Tokat'ta Osmanlı Devri Mimari Eserleri, İstanbul Üniversitesi Edebiyat Fakültesi Türk İslam Sanatı Kürsüsü Lisans Tezi, İstanbul 1966, s. 24-28; Ali Osman Uysal, "Tokat’taki Osmanlı Camileri”, Türk Tarihinde ve Kültüründe Tokat Sempozyumu, Ankara 1987, s. 351-352.

31 Uysal, a.g.e., s. 351-352; Nuri Seçgin, Tokat’taki Türk Mimari Eserleri, Mimar Sinan Üniversitesi Sosyal Bilimler Enstitüsü, Arkeoloji ve Sanat Tarihi Anabilim Dalı, Türk ve İslam Sanatları Programı, Yüksek Lisans Tezi, İstanbul 1993, s. 14.

32 Semavi Eyice, “Ali Paşa Camii”, Türkiye Diyanet Vakfı İslam Ansiklopedisi, C. 2, İstanbul 1989, s. 430; Seçgin, a.g.e., s. 14. 
açıklıklı birer mahfil burada da yer almaktadır. Nişleri oluşturan duvar payelerinin durumundan anlaşıldığı üzere, payelerin üst örtüyü taşıma fonksiyonları bulunmaktadır. Hem trompların, hem de nişlerin üzerinde yer alan mahfillerin kemerleri, yine Diyarbakır Behram Paşa Camii’nde olduğu gibi mukarnaslı düzenlemelerle duvar payelerine oturmaktadir (G. 27).

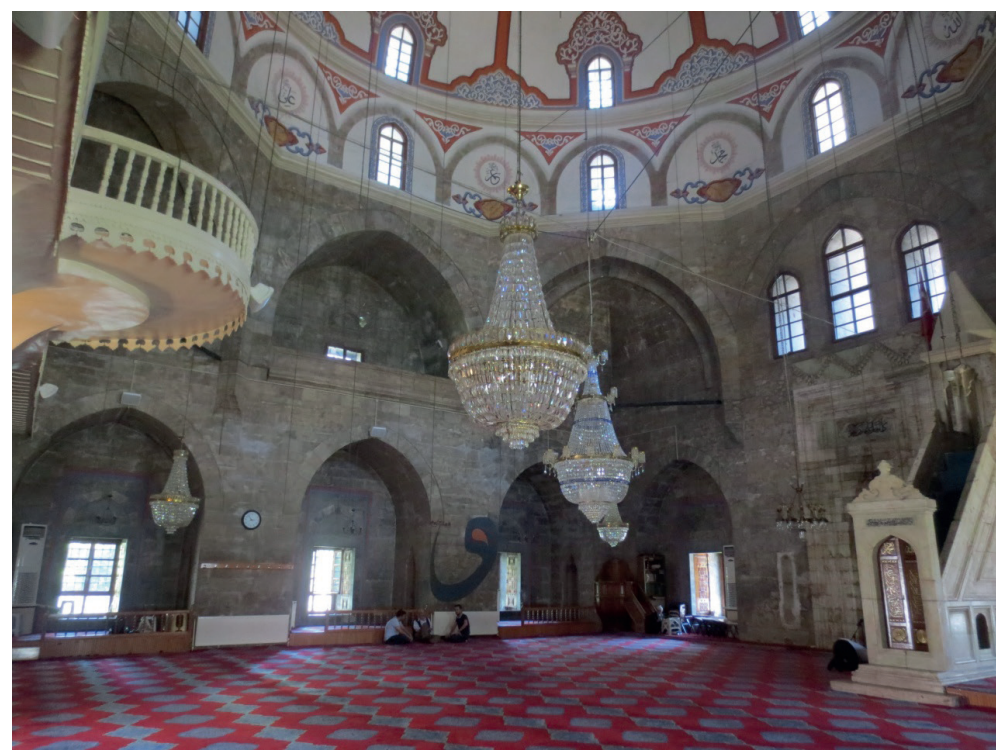

G. 25. Tokat, Ali Paşa Camii, Harim Mekanı (Ayşe Denknalbant Çobanoğlu, 2017)

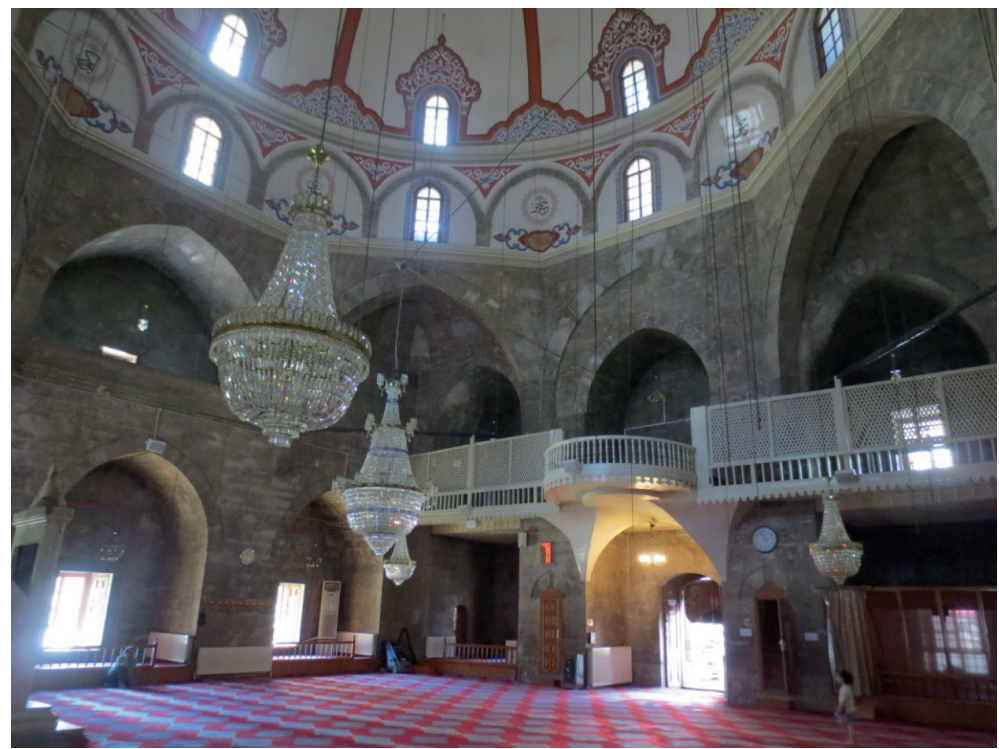

G. 26. Tokat Ali Paşa Camii, Doğu ve Kuzey Cepheler (Ayşe Denknalbant Çobanoğlu, 2017) 


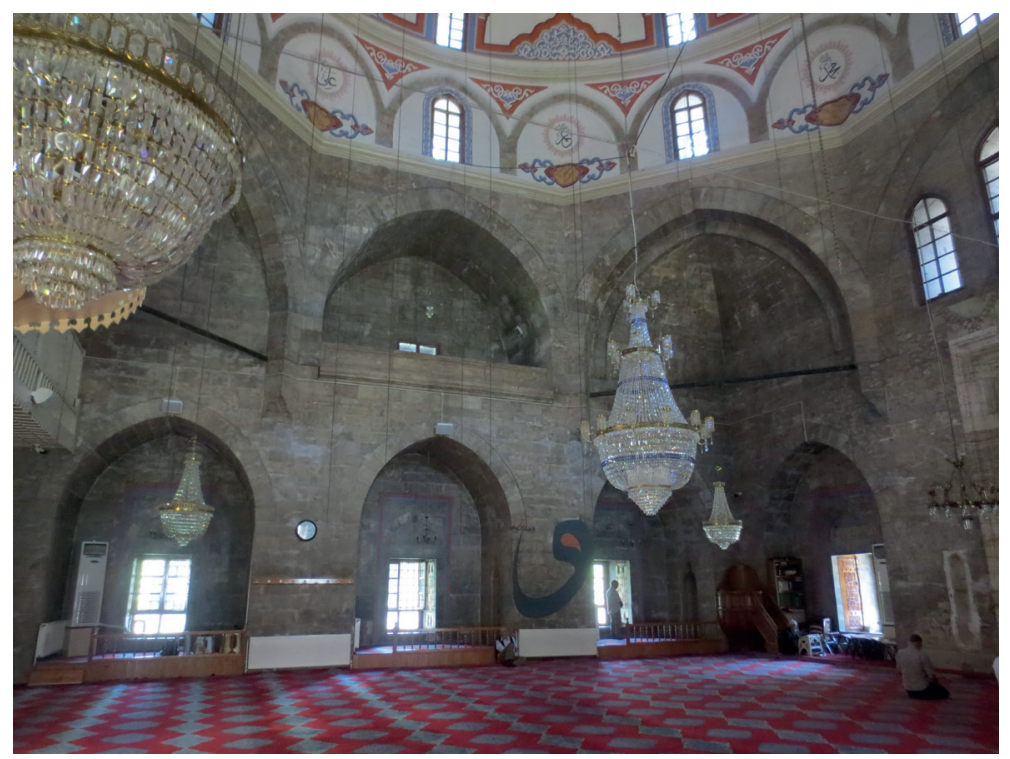

G. 27. Tokat Ali Paşa Camii, Batı Cephe (Ayşe Denknalbant Çobanoğlu, 2017)

Bali Paşa Camii ile benzer düzenlemeyi ise Kayseri Hacı (Doğancı) Ahmed Paşa Camii (Kurşunlu Camii)'nde görmekteyiz. A. Gabriel, yapının banisinin Ahmet Paşa olduğunu ve doğrudan Mimar Sinan’ın inşa ettiği yapılar içinde olmasa bile, en azından planının onaylanması bakımından Mimar Sinan’la ilişkisi bulunduğunu söylemektedir ${ }^{33}$. Ahmed Paşa, sarayda doğancıbaşı olarak yetiştirildikten sonra saray ahırlarının başı olmuş ve 1558'de Karaman Beylerbeyliği'ne atanmıştır. Görevleri bittiğinde İstanbul'a yerleşen paşanın Üsküdar civarında da eserleri vardır. Kendisi de Mimar Sinan'ın Üsküdar'da inşa ettiği türbesinde gömülmüştür. Hacı Ahmed Paşa, Kayseri'de banisi olduğu yapıları, burada Karaman Beylerbeyi olarak görev yaptığı dönemin anısı için inşa ettirmiş olmalıdır. Yapının vakfiyesi 1581-82 tarihli olduğu için caminin bu tarihte tamamlanmış olduğu düşünülse de, kitabesinde ebced hesabiyla verilen tarihi $1585-86{ }^{\prime} \mathrm{d}_{1} \mathrm{r}^{34}$.

33 Albert L. Gabriel, Monuments Turcs d'Anatolie, Paris 1931, Anadolu'da Türk Anıtları Kayseri, Çev. M. Akif Tütenk, Haz. Faruk Yaman, Kayseri 2009, s. 120-121; Aslanapa, a.g.e., s. 298; Alper Ertunga, Kayseri Camileri, İstanbul Üniversitesi Edebiyat Fakültesi Sanat Tarihi Bölümü Türk İslam Sanatı Kürsüsü Lisans Tezi, İstanbul 1974, s. 39-42.

34 Necipoğlu, a.g.e., s. 607-608. 

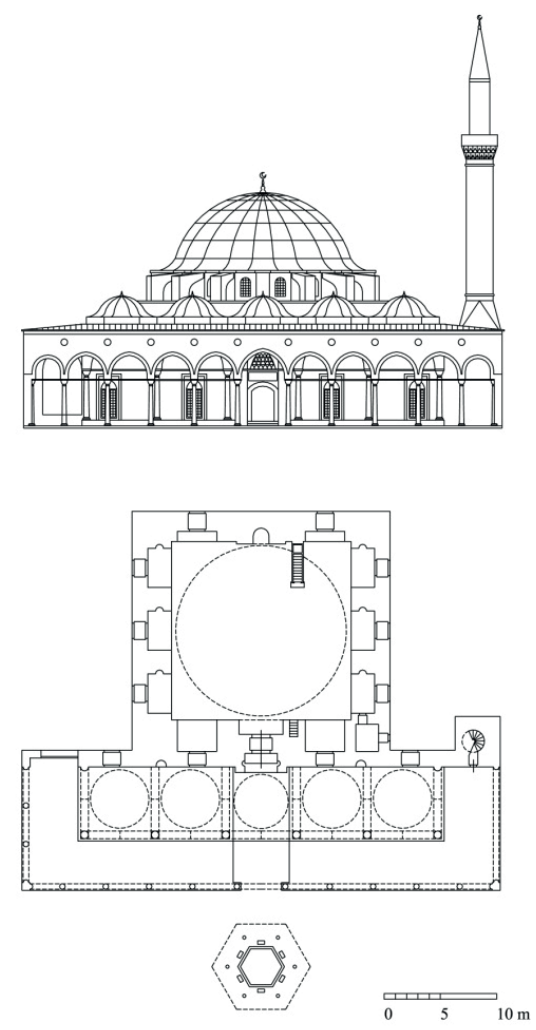

G. 28. Kayseri Hacı Ahmed Paşa Camii, Plan (G. Necipoğlu, 2013)

Çalışmaya dâhil ettiğimiz diğer yapılara benzer olarak Kayseri Hacı Ahmed Paşa Camii de kesme taşla inşa edilmiş ve kare planlı bir yapı olup üzeri pandantiflerle geçişi sağlanan tek kubbeyle örtülüdür. Ölçülerinin yüksek tutulduğu anlaşılan yapının hem kuzeybatı hem de kuzeydoğusunda minare olduğu bilgisi olmasına rağmen günümüzde yalnızca kuzeybatı yöndeki minare bulunmaktadır³5 (G. 28).

Yapının kuzey cephesinde altı adet sütunun taşıdığı sivri kemerlerle bölümlenmiş beş gözlü son cemaat yeri bulunmaktadır. İki yandan dışa taşkın olan son cemaat yeri, meyilli çatıya sahip bir revakla çevrelenmiştir (G. 29). Duvar payelerinin iç mekândaki çıkıntılarından dolayı, doğu ve batı duvarda üçer, kuzey duvarda ise iki tane derin niş oluşmuştur. Bu nişlerin üzerinde de tıpkı Bali Paşa Camii’nde olduğu gibi, nişlerin boyunca mahfiller yer almaktadır (G. 30). Mahfillerin nişlerin üzerindeki konumlanışı, yani payelerin üst örtüyle ilişkisinin kesilmiş olması, bize buradaki payelerin de taşıyıcı konumda olmadıklarını vurgulamakta, kubbe pandantiflere oturmaktadır (G. 31). 


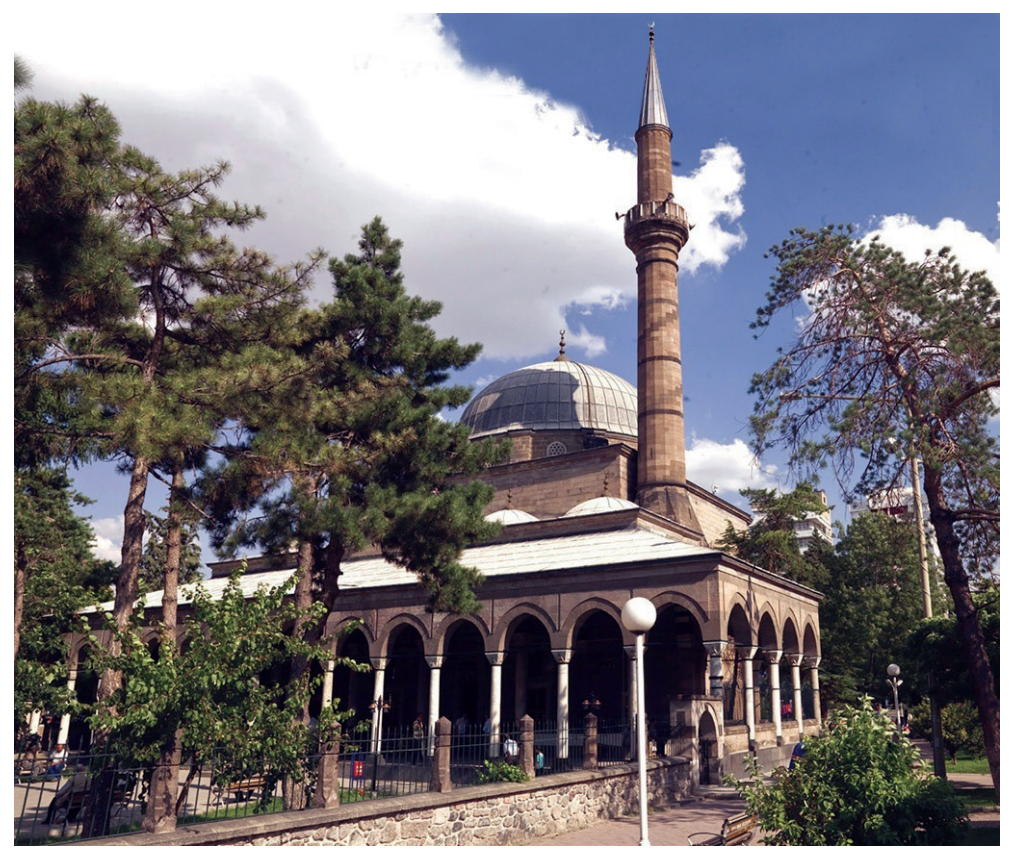

G. 29. Kayseri Hacı Ahmed Paşa Camii (www.kayseri.bel.tr)

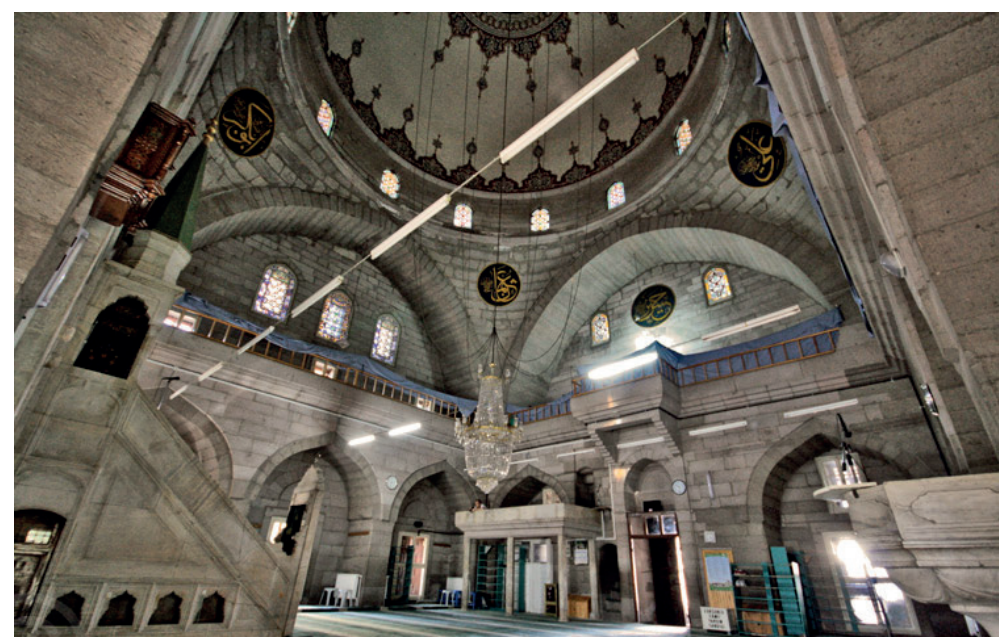

G. 30. Kayseri Hacı Ahmed Paşa Camii, Harim Mekânı (www.kayseridenbiz.com) 


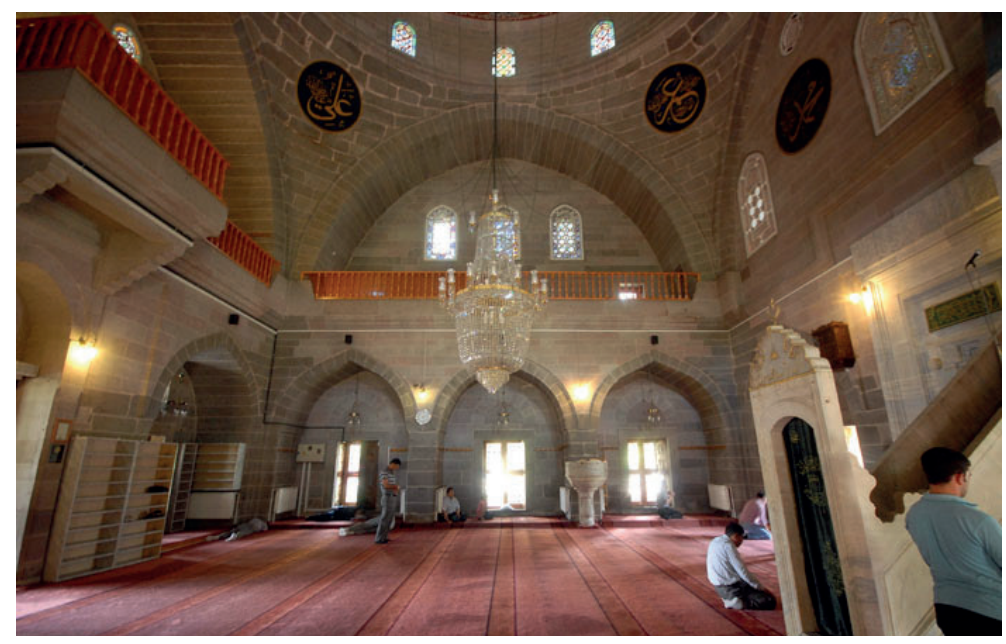

G. 31. Kayseri Hacı Ahmed Paşa Camii, Batı Cephe (www.mustafacambaz.com)

Çalışma konusu olarak ele aldığımız bu plan tipindeki yapılar, İstanbul ve Anadolu dışında, o dönemde Osmanlı İmparatorluğu'nun hâkim olduğu Bağdat ve Halep gibi eyalet merkezlerinde de karşımıza çıkması açısından da önemlidir. Yapıların görüldüğ̈̈ 16. Yüzyılın ikinci yarısından itibaren, bu eyalet merkezlerinde yapılarını inşa ettiren banilerin (belki de daha önceden bildikleri) ve Mimar Sinan'ın bu planı tercih ettikleri, hem Diyarbakır hem de Halep’teki iki yapının banisi olan Behram Paşa örneği düşünüldüğünde akla gelmektedir.

Bağdat Abdülkadir Geylani Camii, Kanuni'nin 1534’teki Irak Seferi sırasında Mimar Sinan'a Abdülkadir Geylani için inşa ettirdiği türbe, medrese ve imaretlerden oluşan külliyenin bir parçasıdır ${ }^{36}$. Cami ve türbe etrafı kubbeli revaklarla çevrili bir alanda yer almakta olup tekke, medrese ve imaret gibi yapılar ise camiyi çevreleyen avluya yerleştirilmiştir. Külliyenin güneyinde geniş bir haziresi de bulunmaktadir ${ }^{37}$. Caminin doğusunda ve camiyle birlikte planlanmış olan türbeyle cami arasında geçiş bulunmakta olup bu kapı harime, doğu yöndeki nişin içine açılmaktadır. Caminin harim mekânında yine sekiz kalın payenin duvarlardan çıkıntılı olarak yerleştirilmesi ile her cephede ortadakiler geniş iki yandakiler daha dar olmak üzere üçer niş meydana getirilmiştir (G. 32). Cami, tromplarla geçilen bir kubbe ile örtülüdür. Mihrap cephesi dişında, diğer üç yönde bu nişlerin üzerine mahfiller yerleştirilmiştir. Fatih Bali Paşa, ve Kayseri Hacı Ahmed Paşa Camii örneklerinde de olduğu gibi, bu mahfiller payelerin üst örtüyle bağlantısını kesmektedir; bu şekliyle de payelerin yine mahfilleri taşımaktan öte bir görevi olmadığı anlaşılmaktadır ${ }^{38}$.

36 Abdüsselam Uluçam, "Bağdad'da Abdülkadir Geylanî (K. S.) Külliyesi”, Vakıflar Dergisi, S. 20, Ankara 1988, s. 63; Abdüsselam Uluçam, Irak'taki Türk Mimari Eserleri, Ankara 1989, s. 31.

37 Uluçam, a.g.e., 1988, s. 64; Uluçam, a.g.e., 1989, s. 32.

38 Uluçam, a.g.e., 1988, s. 64-65; Uluçam, a.g.e.,1989, s. 33-34. Uluçam, duvar payeleri üzerinde yer alan 


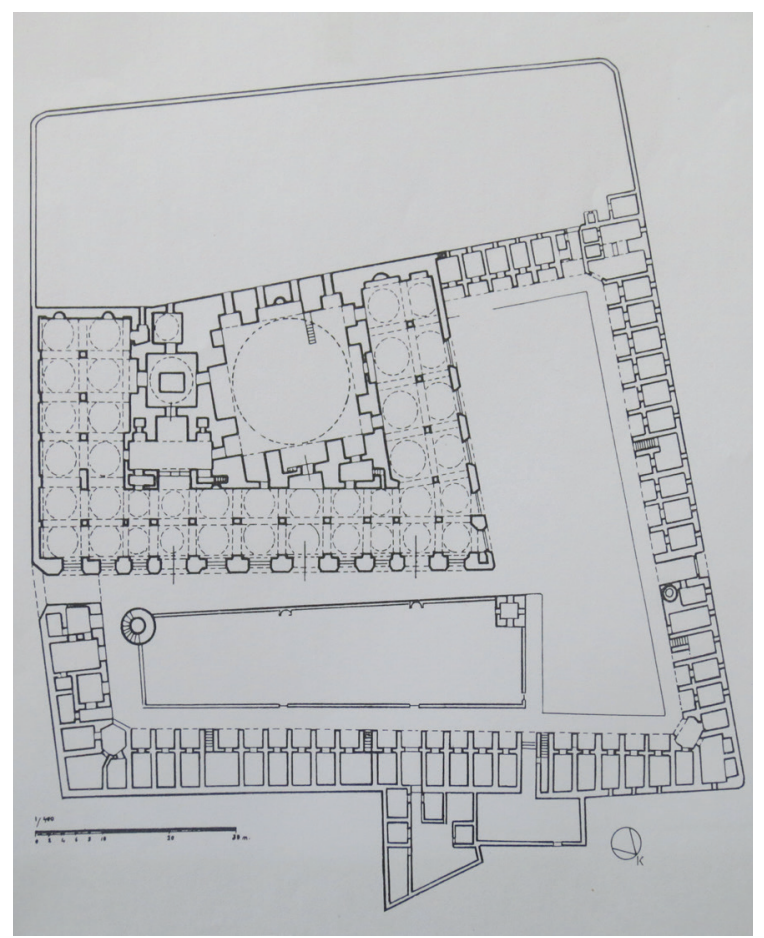

G. 32. Bağdat Abdülkadir Geylani Camii Planı (A. Uluçam, 1989)

Halep Dukakinzade (Adiliye) Camii, Sultan I. Selim'in sadrazamlarından Dukakinzade Ahmed Paşa'nın oğlu Mehmed Paşa tarafından inşa ettirilmiştir. Mehmed Paşa 1551-1553 yılları arasında Halep Beylerbeyliği görevinde bulunmuştu ${ }^{39}$. Araştırmacılar yapının inşa tarihi hakkında farklı görüşler ileri sürmüşlerdir. Yapının vakfiyesi göz önüne alındığında inşasına 1556'da başlandığı ve Mehmed Paşa'nın ölümünden sonra 1565-66 y1llarında tamamlandığı görüşünün yanında ${ }^{40}, 1555,1556$ yıllarına da tarihlenmektedir ${ }^{41}$. Cami, etrafında inşa edilmiş dükkânlardan oluşan ticaret merkezinin güneyinde yer almaktadır. Şadırvanlı avludan geçilerek iki kademeli son cemaat yerine ulaşılmaktadır. Dıştaki son cemaat yeri mukarnaslı başlıklara sahip on sütunla taşınan sivri kemerli düzenlemeli olup içteki son cemaat yeri ise yine mukarnaslı başlıklara sahip beş sütunun taşıdığı sivri kemerli düzenlemelidir.

mahfillerin düzenlerinin Fatih Bali Paşa Camii’nin benzeri olduğunu özellikle belirtmektedir.

39 A. Hadjar, Historical Monuments of Aleppo, Translated by Khaled Al-Jbaili, Aleppo 2006, s. 103; Kemal Hakan Tekin, Halep’teki Osmanlı Dönemi Dini Eserleri, Erciyes Üniversitesi Sosyal Bilimler Enstitüsü, İslam Tarihi ve Sanatları Anabilim Dalı Doktora Tezi, Kayseri 2008, s. 132.

40 Necipoğlu, a.g.e., s. 634.

41 Çiğdem Kafesçioğlu, "In Image of Rûm: Ottoman Architectural Patronage In Sixteenth Century and Damascus”, Muqarnas, V. 16, 1997, s. 71; L. Jasser, S. Khalaf, A. Sabbağ, A. Mamo, Halep'te Osmanlı Döneminde İnşa ve Tadil Edilen Mimari Eserlerin Envanteri, Ed. Ahmet Özpay, H. İbrahim Yakar, Gaziantep 2010, s. 22. 
Minare, caminin kuzeybatı köşesinde yer almaktadır (G. 33, G. 34). Çift renkli taş örgülü taçkapıdan ulaşılan harim mekânını mukarnas dolgulu tromplarla geçişi sağlanan bir kubbe örtmektedir. Caminin harim mekânında, kuzey, doğu ve batı cephelerine duvarlardan taşkın olarak yerleştirilmiş olan payeler, bu yönlerde üçer adet, kuzey yönde ise iki adet sivri kemerli derin niş oluşmasını sağlamıştır (G. 35). Duvar payeleri, kubbeye kadar yükselmekte olup üzerlerinde payelerin taşıyıcı durumunu engelleyecek şekilde mahfil düzenlemesine yer verilmemiştir. Bu durumuyla da payelerin taşıyıcı özelliklerinin mevcut olduğu görülmektedir. Nişlerin namazlarda da kullanılabilmesi için güney yüzlerine açılmış mihraplar bulunmaktadır. Ayrıca nişlerin içinde, üzerlerinde sivri kemerli çini alınlıklar bulunan dikdörtgen açıklıklı pencereler yer almaktadır (G. 36, G. 37).
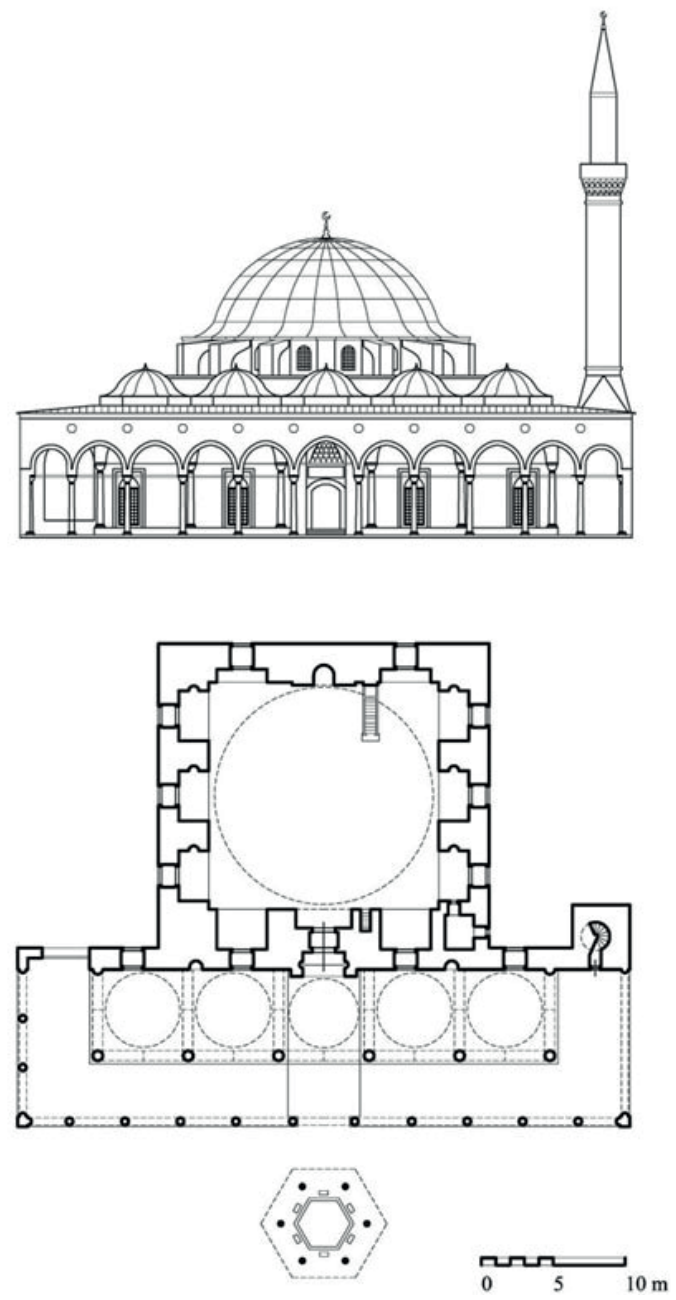

G. 33. Halep Dukakinzade (Adiliye) Camii, Görünüş ve Plan (G. Necipoğlu, 2013) 


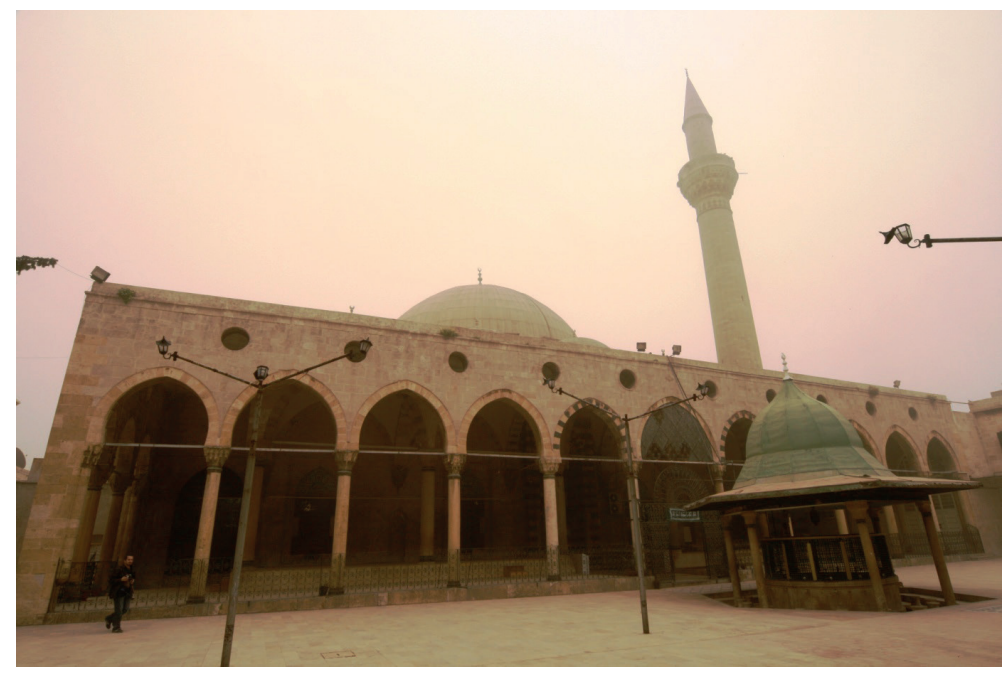

G. 34. Halep Dukakinzade Camii (Ayşe Denknalbant Çobanoğlu, 2007)

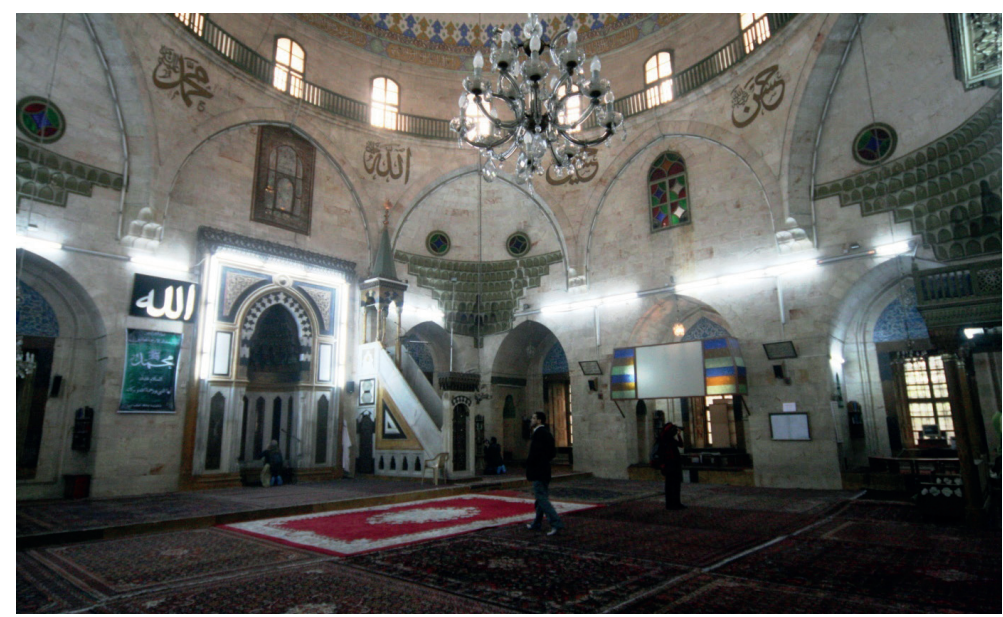

G. 35. Halep Dukakinzade Camii, Harim Mekânı (Ayşe Denknalbant Çobanoğlu, 2007) 


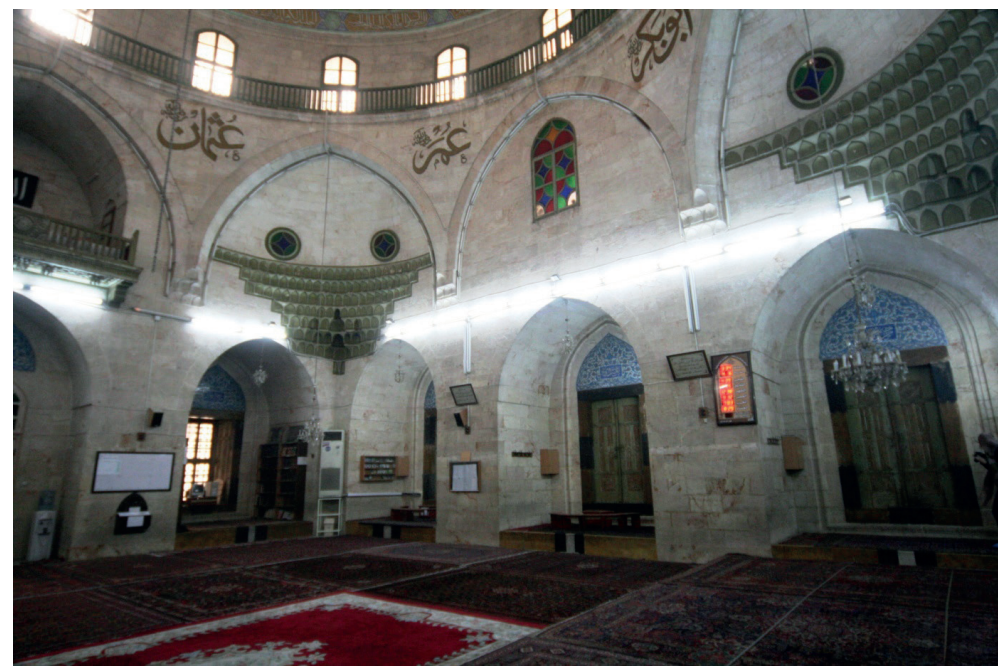

G. 36. Halep Dukakinzade (Adiliye) Camii, Batı Cephe (Ayşe Denknalbant Çobanoğlu, 2007)

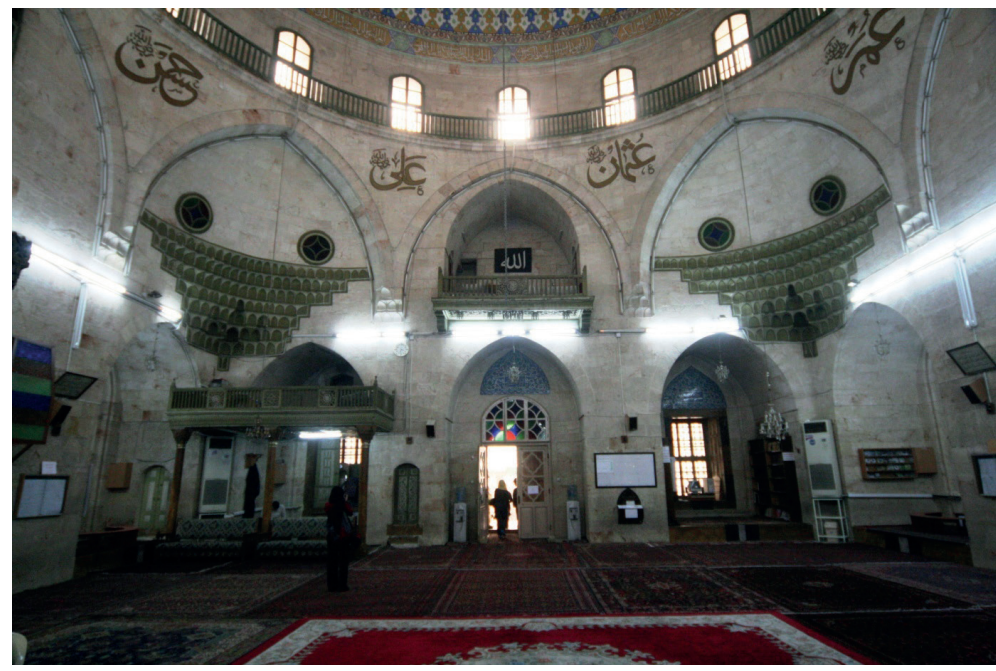

G. 37. Halep Dukakinzade Camii, Kuzey Cephe (Ayşe Denknalbant Çobanoğlu, 2007)

Halep Behram (Behramiye) Paşa Camii, yukarıda bahsettiğimiz Diyarbakır'da kendi adıyla anılan caminin de banisi olan Behram Paşa tarafından, 1580'de Halep valisi olmasından sonra, 1580-1583 yıllarında inşa ettirilmiştir ${ }^{42}$. Yapının avlu cephesi kapalı çarşıya bakmakta olup etrafında ticaret merkezi olarak dükkânlar bulunmaktadır. Diğer cepheleri, şehir dokusunu meydana getiren dar sokaklar ile çevrelen-

42 Hadjar, a.g.e., s. 135; Tekin, a.g.e., s. 65, 158; Necipoğlu, a.g.e., s. 623; Kafesçioğlu, a.g.e., s. 72; Jasser, Khalaf, Sabbağ, Mamo, a.g.e., s. 44. Behram Paşa’nın 1578 yılında Halep'e tayin edildiği yönünde de bilgi 
miştir. Şadırvanlı avludan geçilerek ulaşılan yapının altı sütun ve dört ayak tarafından taşınan on gözlü son cemaat yeri bulunmaktadır (G. 38, G. 39). Cami, kare planlı harimi örten tek kubbeye sahipken, bu kubbe 1821 yılında yıkılmış, 1860'ta bunun yerine dört kare ayak üzerinde taşınan bir kubbe inşa edilmiştir ${ }^{43}$. Mihrap bölümünün oldukça geniş ve dışa taşkın bir şekilde planlanması konu aldığımız diğer yapılardan farklı olmakla birlikte, kare planlı harimde duvar payeleri ile elde edilen doğu ve batıda üçer, kuzey yönde ise iki adet sivri kemerli derin nişle oluşturulan düzenleme benzer özelliktedir (G. 40). Nişlerin içinde, pencere alınlığı olarak kullanılan çiniler natüralist üsluptadır. Bu yapıda da üst katta mahfil düzenlemesi görülmektedir. Diğer örneklerde (Diyarbakır, Tokat) olduğu gibi, mahfiller ortadaki nişlerin üzerinde yer almıştır. Harim mekânını üç yönden saran mahfiller, farklı bir düzenleme olarak, iç mekâna bir sütunun taşıdığı iki sivri kemerle açılmaktadır (G. 41, G. 42). Duvar payelerinin üst örtüyle olan ilişkisi takip edildiğinde, mahfil düzenlemesinin payeleri kesmediği, böylece payelerin üst örtüye destek fonksiyonlarının devam ettiği tespit edilebilmektedir.

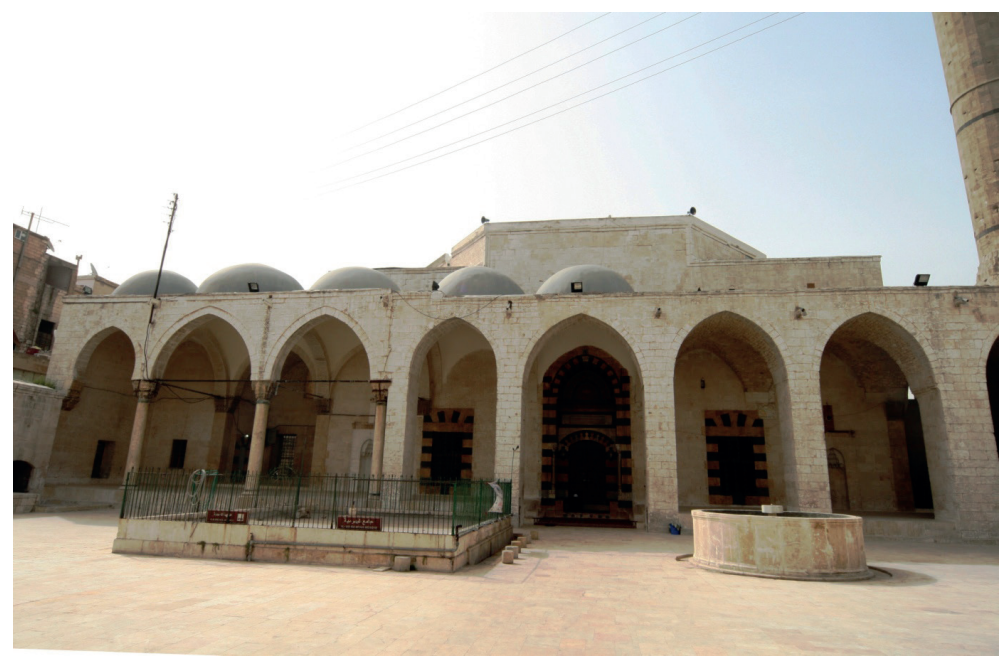

G. 38. Halep Behram Paşa Camii, (Ayşe Denknalbant Çobanoğlu, 2007)

bulunmaktadır. Kaçan Doğan, a.g.e., s. 2-3.

43 L. Jasser, S. Khalaf, A. Sabbağ, A. Mamo, a.g.e., s. 44. 


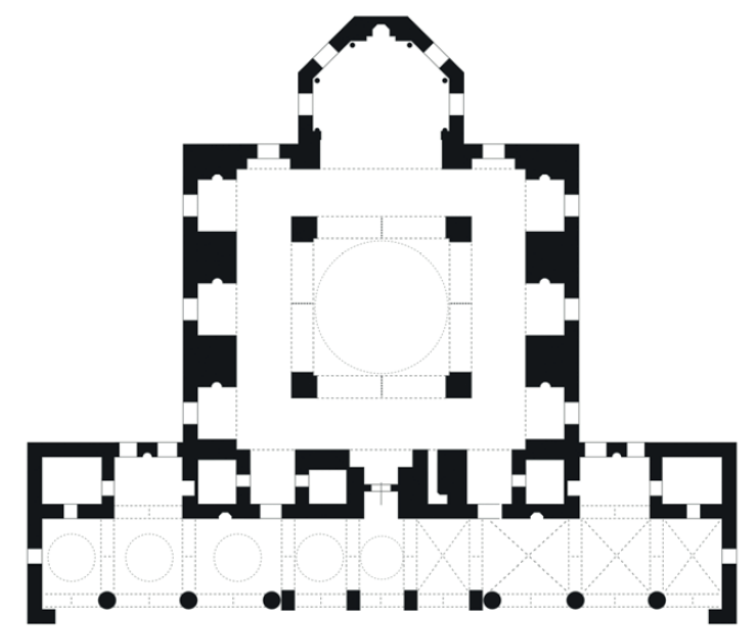

G. 39. Halep Behram Paşa Camii, Plan (K. H. Tekin, 2008)

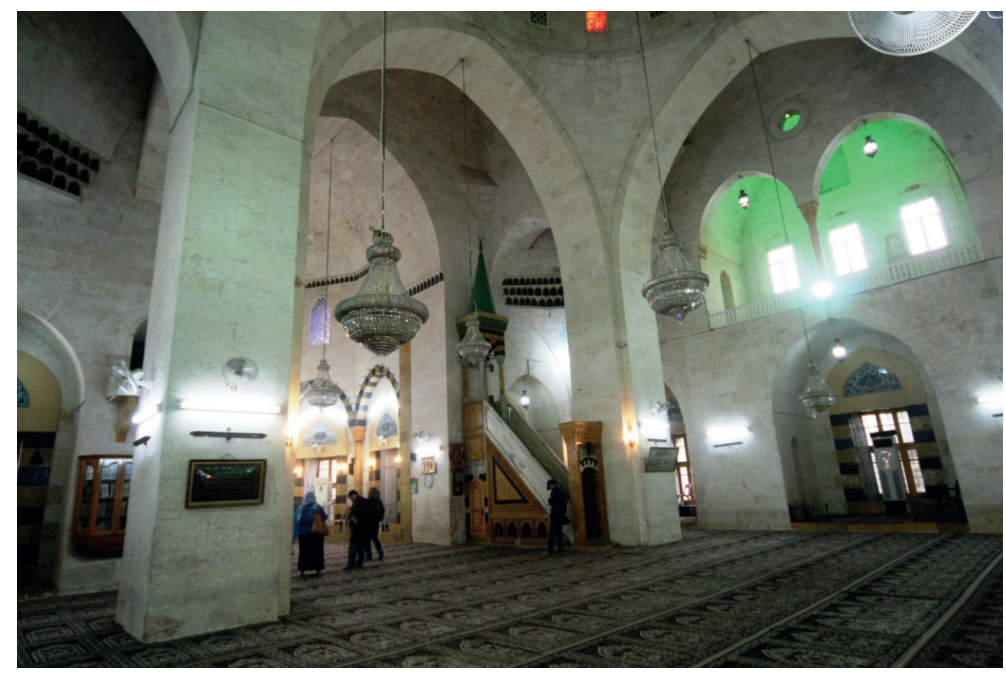

G. 40. Halep Behram Paşa Camii, Mihrap ve Doğu cepheleri (Ayşe Denknalbant Çobanoğlu, 2007) 


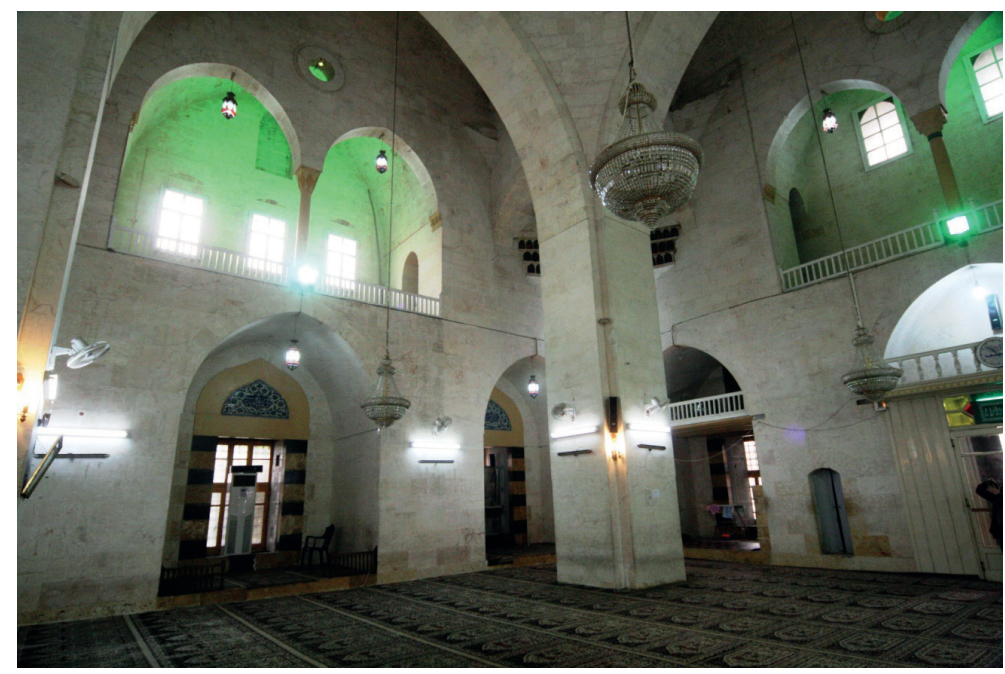

G. 41. Halep Behram Paşa Camii, Harim Mekânı (Ayşe Denknalbant Çobanoğlu, 2007)

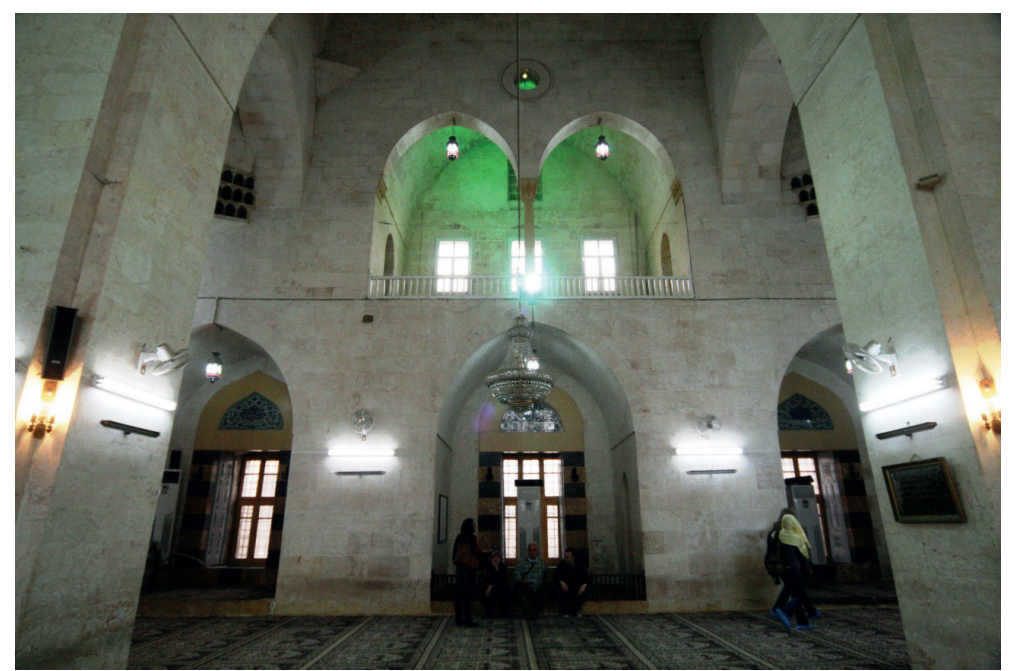

G. 42. Halem Behram Paşa Camii, Batı Cephe (Ayşe Denknalbant Çobanoğlu, 2007) 


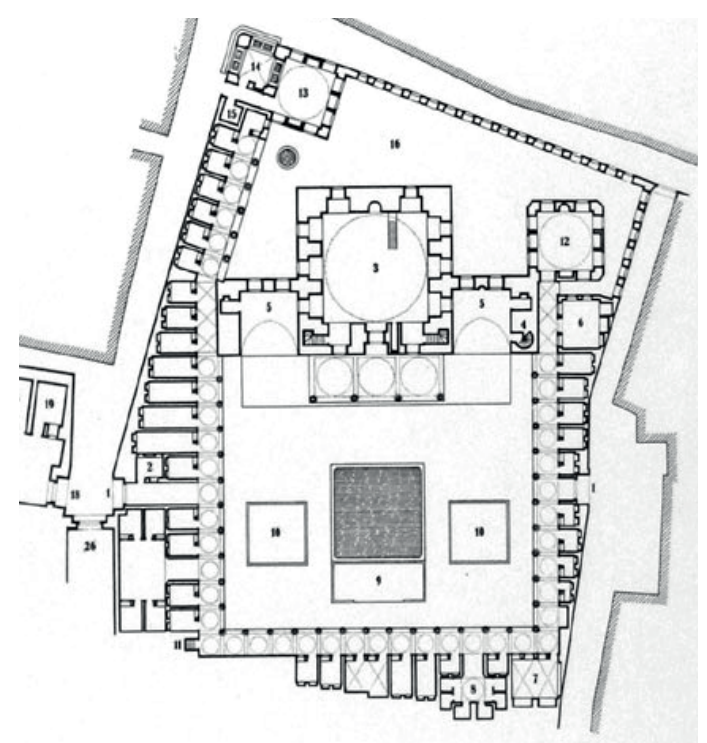

G. 43. Halep Osman Paşa Camii, Plan (K. H. Tekin, 2008)

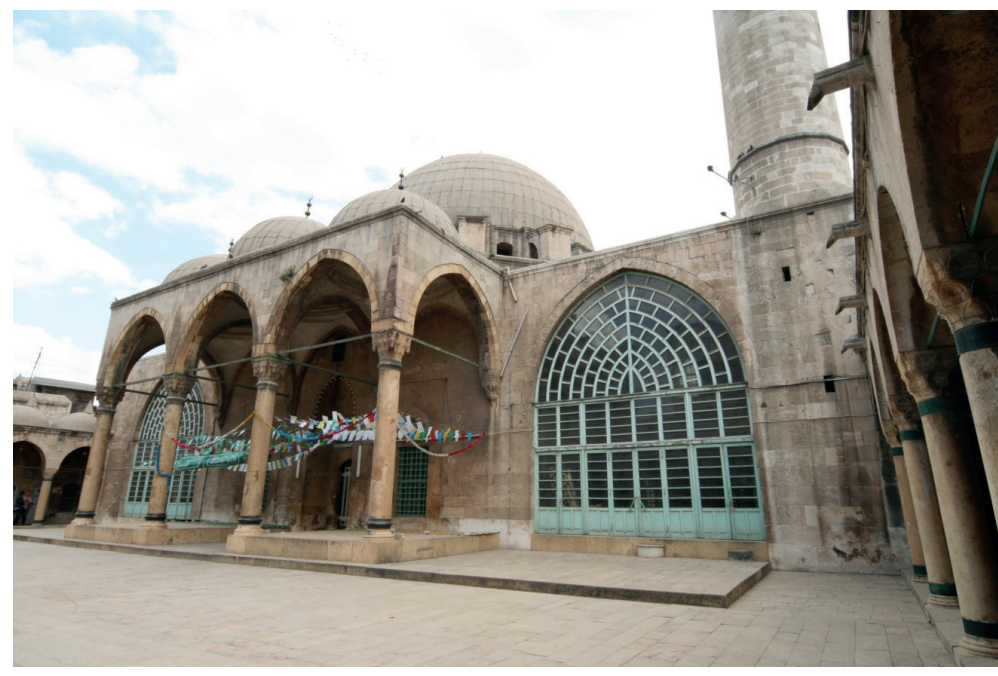

G. 44. Halep Osman Paşa Camii (Ayşe Denknalbant Çobanoğlu, 2007) 


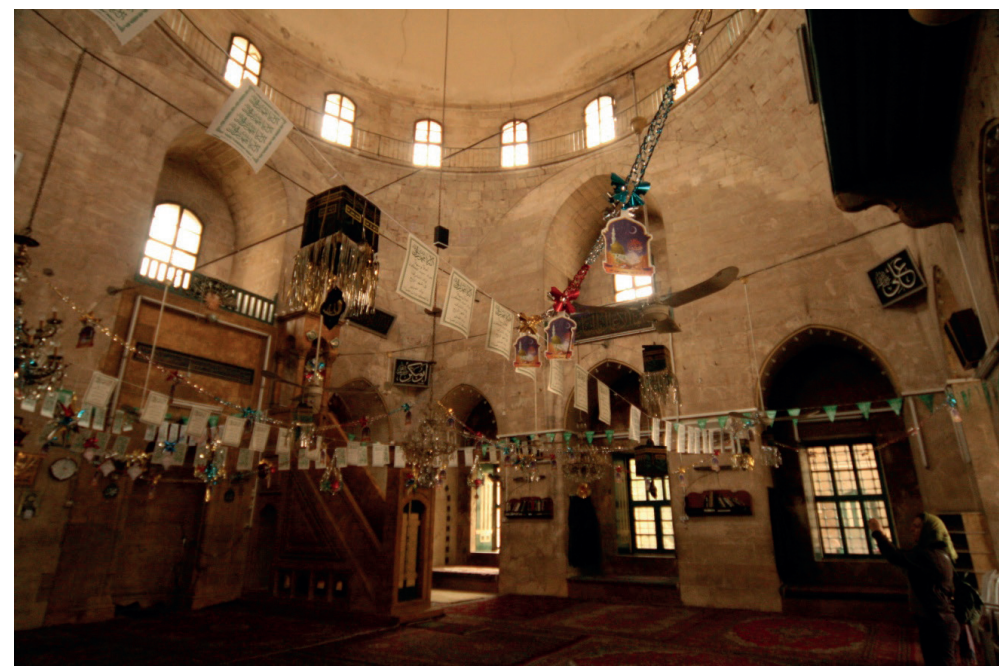

G. 45. Halep Osman Paşa Camii, Doğu Cephe (Ayşe Denknalbant Çobanoğlu, 2007)

\section{Değerlendirme}

Çalışmaya konu edindiğimiz yapılar, Mimar Sinan’ın Mimarbaşı olduğu dönem içindedir ve ele aldığımız örneklerden anladığımız kadarıyla bu plan tipine sahip yapılar 16. yüzyılın ortalarında belirip, bu yüzyılın sonuna kadar kendilerine uygulama alanı bulurlar ${ }^{44}$. Bu plan tipinde, kare planlı yapıların harim mekânında, doğu, batı, kuzey ve bazı örneklerde de güney duvarlarında payeler kullanılmasıyla meydana getirilen derin nişlerin iç mekânda sağladığı yanlara açılma ve genişlik göze çarpmaktadır. Kare planlı bu yapıların üst örtüsü olarak kullanılan kubbelere bazı örneklerde içleri mukarnaslı ya da istiridye yivli tromplarla, bazılarında da pandantiflerle geçilmektedir. Sözünü ettiğimiz hemen hemen bütün yapıların, bazılarında köşe odası yer alması, bazılarında iç mekândaki niş sayıları gibi farklılıklar dışında yatayda planı aynı görülmektedir. Ancak düşeyde bu durum, kubbenin sekiz destekli şema ya da tromp-pandantif tarafından taşınma alternatifiyle farklılık arz etmektedir. Bu durumda ele aldığımız yapılardaki uygulamayı, planın yatayda aynı, ancak düşeyde farklı olması sebebiyle iki gruba ayırmak mümkün görünmektedir. Metinde kronolojik olarak verilmeye çalışılan yapıların bu iki varyasyon düşünülerek değerlendirilmesi yapılabilir. İlk gruptaki yapılar, hem harim mekânında duvarlarda kullanılan payeler sayesinde oluşan derin nişlerle iç mekân algısında genişleme yo-

$44 \mathrm{Bu}$ plan tipinin XVIII-XIX. yüzyıllara ait örnekleri İstanbul ve Anadolu dışında birkaç örnekte daha uygulanmış olarak görülmektedir. Bu örnekler, Halep’te XVIII. yüzyıl yapısı olan Vezir Osman Paşa Camii, (bkz. Meral Ferlibaş Bayrak, "Halep’te XVIII. Yüzyıla Ait Bir Vakıf Örneği: Vezir Osman Paşa Külliyesi”, Türk Kültürü İncelemeleri Dergisi, S. 22, İstanbul 2010, s. 27-84; Tekin, a.g.e., s. 246-262. (G. 43-45); Osmanlı döneminde Halep'te inşa edilen son cami olan 1899 tarihli Zeki Paşa Camii, (bkz. L. Jasser, S. Khalaf, A. Sabbağ, A. Mamo, a.g.e., s. 134-135; Tekin, a.g.e., s. 289-296) olarak karşımıza çıkmaktadır. 
lunda bir adım olmuş, hem de kubbenin bu payelerin oluşturduğu sekizgen şemayı kullanması sonucunda sekiz destekli yapılar içinde de değerlendirilebilir konuma gelmişlerdir. Bu yapılarda harim mekânındaki payelerin üst örtüyle ilişkisini kesecek bir uygulamaya gidilmemiştir. Silivrikapı Hadım İbrahim Paşa Camii (1551), sekiz destekli şemanın değil, ancak payelerin iç mekândan böyle algılanıp hem nişler oluşturması hem de kubbenin sekiz destekle taşınan bir strüktür haline gelmesi yolundaki ilk örnektir. Kilis Canbolat Paşa Camii (1553), Silivrikapı Hadım İbrahim Paşa Camii'ne çok yakın bir tarihte karşımıza çıkmaktadır. Plan aynı gibi görünmekle birlikte, kuzey cephede iki köşeye yerleştirilen köşe odaları, harim mekânında payelerle sağlanan nişlerin eşit geniş ve yükseklikte olması gibi noktalarla Silivrikapı Hadım İbrahim Paşa Camii’nden farklı özellikler de göstermektedir. Diyarbakır Behram Paşa Camii (1564-73)'nde sözünü ettiğimiz plan üzerinde, yine yapıya özgü bazı uygulamalar ve düzenlemelerle karşılaşılmaktadır. Harim mekânındaki payelerin oluşturduğu nişlerin üzerine küçük birer mahfil yerleştirilmesi farklı bir özellik olarak bu yapıda dikkatimizi çekmektedir. Ancak buradaki mahfiller payelerin üst örtüyle olan ilişkisini kesmeyecek şekilde taşıyıcıların aralarına yerleştirilmiş olup aralarının kemerlerle bağlanması suretiyle sekizgen strüktürü yine desteklemektedir. Ayrıca, mihrap cephesindekiler iki katlı olmak üzere, yapının dört köşesine yerleştirilen odalar (itikâf hücreleri) da, yapının kuvvetli strüktürüne işaret eden unsurlardır. Bunlardan başka, o dönemde Osmanlı'nın yönetimindeki eyaletlerden Halep'te 1565-66 y1llarında inşa edilen Dukakinzade (Adiliye) Camii de, plan üzerinde bu gruptaki yapılar arasındadır. Tokat Ali Paşa Camii (XVI. yüzyılı üçüncü çeyreği-1572) sözünü ettiğimiz planda ve bu grup içinde değerlendirilen yapılardan biri olup nişlerin üzerindeki mahfil düzenlemesi açısından da Diyarbakır Behram Paşa Camii'ne benzemektedir. Diyarbakır Behram Paşa Camii'ni inşa ettiren Behram Paşa'nın Halep'te yine banisi olduğu Behramiye Camii (1580-83) de payelerin sağladığı niş alanları ve üzerlerindeki mahfilli düzenlemeleriyle bu grup içindeki bir diğer örnektir. Behram Paşa'nın daha önce gördüğü ve benimsediği Halep Dukakinzade (Adiliye) Camii'nin plan kuruluşunu, önce Diyarbakır'da, daha sonra ise Halep’te inşa ettirdiği iki yapısında da, sipariş ederken tercih etmiş olabileceği akla gelmektedir.

İkinci grup olarak bahsedebileceğimiz yapılardan Fatih Bali Paşa Camii, yapılış tarihi 1546 olarak kabul edildiğinde, ele aldığımız örnekler içinde en erken tarihli yapı olarak karşımıza çıkmaktadır. Bu yapıda az önce belirttiğimiz yataydaki plan benzerliği devam etmekte, ancak harim mekânında payelerle oluşturulan nişlerin üzerinde boylu boyunca yer alan mahfiller payelerin üst örtüyle olan ilişkisini kesmektedir. Böylece, ilk grup içinde bahsettiğimiz yapılardan farklı olarak payelerin sekizgen strüktürü destekleme fonksiyonları bulunmamaktadır. Harim mekânındaki nişlerin içeride sağladığ 1 genişlik hissi, nişlerin üzerinde yer alan mahfillerce de vurgulanmakta, bu suretle harim mekânı basık bir izlenim yaratmamaktadır. Kay- 
seri Hacı Ahmed Paşa Camii'nde (1585-86) de benzer olarak harim mekânındaki payelerin aralarında oluşan derin nişlerin üzerinde yer alan mahfil düzenlemeleri, payelerin yapının üst örtüsüyle olan ilişkisini kesmiş, bunların yalnızca harim mekânındaki farklı bir düzenleme unsuru konumunda olmalarını sağlamışlardır. Kayseri Hacı Ahmed Paşa Camii'nin bu grup içinde değerlendirilen planı için de, yine bir süre Halep'te görev yapmış olan banisinin, Dukakinzade ve Behramiye Camii'lerini görerek, Kayseri'de benzer bir yapı yaptırma isteğinin oluştuğu düşünülebilir. Anadolu dışında, yine döneminde Osmanlı'nın hâkim olduğu topraklardan Bağdat'ta Abdülkadir Geylani Camii (1534), etrafındaki yapılar topluluğu içinde, türbeyle bağlantılı bir konumda olup harim mekânı düzenlemesi ve üst örtünün taşınması strüktürü açısından ikinci grup olarak belirttiğimiz yapılarla paralellik göstermektedir.

Sonuç olarak yukarıda da vurguladığımız gibi, çalışmada ele aldığımız yapılar 16 . yüzyılın ikinci yarısından itibaren, birbirlerine oldukça yakın tarihlerde, hatta bazen aynı baniye sahip olarak inşa edilmişlerdir. Yapılardan bazılarının Mimar Sinan'ın tezkirelerinde isimlerinin zikredilmesiyle doğrudan ona mal edilen yapılar olmasının yanında, bazılarının da onun Mimarbaşı olduğu bu dönemde, eldeki mevcut plana göre değerlendirilerek inşa edildikleri tahmin edilmektedir. Yapıların planlarının yatayda benzer olması, bazen bütün örneklerin aynı plana dâhil oldukları yönünde değerlendirilmelerine neden olmuş, ancak taşıyıcı strüktür açısından değerlendirildiklerinde farkları ortaya konmuştur. Kabaca bakıldığında aynı gibi görünen bu plan tipinin, iki varyasyon altında incelenmesine yol açan sekiz destekli strüktür uygulanması ya da uygulanmaması dışında, aslında, bazen yapıların konumlanışına göre daha yüksek bir kübik gövdeye sahip olması (Silivrikapı Hadım İbrahim Paşa Camii, Kayseri Hacı Ahmed Paşa Camii), bazılarında ihtiyaca binaen köşe odalarının yerleştirilmesi (Kilis Canbolat Paşa Camii ve Diyarbakır Behram Paşa Camii) gibi özelliklerle de karşımıza çıkması, elde bulunan planın, her ihtiyaç hâsıl olduğunda aynen uygulanmadığı, yapıların özelinde onlara uygun çözümlerin üretildiğine de işaret etmektedir. Böylece, kubbenin taşınma strüktürü bakımından iki değişik çözümle uygulanan bu plan, hem harim mekânın her yöne genişlemesi suretiyle farklı bir sonucu daha getirmiş, hem yapıların özellerinde uygulanan çözümler itibariyle kendi içinde farklı özellikler de geliştirmiştir. Çok çeşitli ve yetkin örneklerle dolu 16. yüzyıl Osmanlı Mimarlığı içinde bu yapılar belki küçük bir grup gibi görünse de, Mimar Sinan'ın (ve belki Mimarbaşı olduğu dönemin yetiştirdiği mimarların da) geliştirdikleri bir plan üzerinde fikri sabit kalmayıp, her yapıya uygun çözüm üretme ve sonsuz bir arayış heyecanıyla yapıları hayata geçirdiklerini düşünmeyi mümkün kılmakta ve bu konuda örnek olmaktadırlar. 


\section{Kaynakça/References}

AKÇIL HARMANKAYA, N. Çiçek, Mimar Sinan Camilerinde Sembolizm, Mimar Sinan Güzel Sanatlar Üniversitesi, Sosyal Bilimler Enstitüsü, Türk İslam Sanatları Anabilim Dalı, Doktora Tezi, İstanbul 2017.

AKÇIL HARMANKAYA, N. Çiçek, Mimar Sinan Camilerinde Sembolizm, İstanbul 2018.

AKİS, Metin, "İ. Hakkı Konyalı Armağanına Katkı: Kilis Sancağında Canbolat Oğulları Ailesinin Yönetimi”, Şehirlerin Sevdalısı İbrahim Hakkı Konyalı Armağanı, Konya 2015, s. 391-404.

ALTUN, Ara, Ortaçağ Türk Mimarisinin Anahatları İçin Bir Özet, İstanbul 1988.

ASLANAPA, Oktay, Osmanlı Devri Mimarisi, İstanbul 1986.

ATASEVER, Gülümser, Kilis'de Türk Mimari Eserleri, İstanbul Üniversitesi Edebiyat Fakültesi Sanat Tarihi Bölümü Türk Sanatı Kürsüsü Lisans Tezi, İstanbul 1969.

BATUR, Selçuk, "Osmanlı Camilerinde Sekizgen Ayak Şemasının Gelişmesi Üzerine”, Anadolu Sanatı Araştırmaları, I, İstanbul 1968, s. 139-163.

BAYRAK, Meral FERLİBAŞ, “Halep’te XVIII. Yüzyıla Ait Bir Vakıf Örneği: Vezir Osman Paşa Külliyesi”, Türk Kültürü İncelemeleri Dergisi, S. 22, İstanbul 2010, s. 27-84.

BEYSANOĞLU, Şevket, Anıtları ve Kitabeleri ile Diyarbakır Tarihi Akkoyunlular'dan Cumhuriyet'e Kadar, C. 2, Ankara 1996.

CEZAR, Mustafa, "Türk Mimarisinde Kubbe”, Türkiyemiz, C. IX, S. 27, Ankara 1979, s. 32-38.

DÜNDAR, Abdülkadir, Kilis’teki Osmanlı Devri Mimari Eserleri, Ankara 1999.

ERDOĞAN, Meryem KAÇAN, “XVI. Yüzyılda Halep’te Bir Osmanlı Vakfi: Behram Paşa Külliyesi”, Türk Kültürü İncelemeleri Dergisi, S. 22, İstanbul 2010, s. 1-26.

EROĞLU, Süreyya, “Kilis Tekke (Canpolat Paşa) Camisi’nin Mimarisi ve Süslemesi”, 21. Uluslararası Ortaçağ ve Türk Dönemi Kazıları ve Sanat Tarihi Araştırmaları Sempozyumu 25-27 Ekim 2017, Antalya 2017 (Bildiri kitabı baskıda).

ERTUNGA, Alper, Kayseri Camileri, İstanbul Üniversitesi Edebiyat Fakültesi Sanat Tarihi Bölümü Türk İslam Sanatı Kürsüsü Lisans Tezi, İstanbul 1974.

ERZİ İhsan, Camilerimiz Ansiklopedisi, C. 1, İstanbul 1987.

ESİN, Emel, “Türk Kubbesi (Gök-Türklerden Selçuklulara Kadar)”, Selçuklu Araştırmaları Dergisi, C. 3, Ankara 1971, s. 158-182.

EYİCE, Semavi, “Ali Paşa Camii”, Türkiye Diyanet Vakfı İslam Ansiklopedisi, C. 2, İstanbul 1989, s. 430-431.

EYİCE, Semavi, “İstanbul'da Bali Paşa Camii ve Mimar Sinan”, Prof. Dr. Bekir Kütükoğlu'na Armağan, İstanbul 1991, s. 507-524.

EYİCE Semavi, “Bali Paşa Camii”, Dünden Bugüne İstanbul Ansiklopedisi, C. 2, İstanbul 1994, s. 27-28.

EYİCE, Semavi, “İbrahim Paşa Külliyesi”, Türkiye Diyanet Vakfı İslam Ansiklopedisi, C. 21, İstanbul 2000, s. 341-343.

GABRIEL, Albert L., Monuments Turcs d'Anatolie, Paris 1931, Anadolu'da Türk Anıtları Kayseri, Çev. M. Akif Tütenk, Haz. Faruk Yaman, Kayseri 2009.

GÜNKUT, B., Diyarbekir Tarihi, Diyarbakır 1937.

HADJAR, A., Historical Monuments of Aleppo, Translated by Khaled Al-Jbaili, Aleppo 2006. 
İŞMEN, Duran, Hadım İbrahim Paşa Külliyesi, İstanbul Üniversitesi Edebiyat Fakültesi Sanat Tarihi Bölümü Mezuniyet Tezi, İstanbul 1966.

JASSER Lamia; KHALAF, Salem; SABBAĞ, Abbas; MAMO, Adnan, Halep’te Osmanlı Döneminde İnşa ve Tadil Edilen Mimari Eserlerin Envanteri, Ed. Ahmet Özpay, H. İbrahim Yakar, Gaziantep 2010.

KAFESÇİOĞLU, Çiğdem, "In Image of Rûm: Ottoman Architectural Patronage in Sixteenth Century and Damascus”, Muqarnas, V. 16, 1997, s. 70-96.

KAZAN, Hilal, “İstanbul' da Bâli Paşa Vakfiyesi ve Yeni Bilgiler”, Vakıflar Dergisi, S. 29, Ankara 2005, s. 55-75.

KONYALI, İbrahim Hakkı, Abideleri ve Kitabeleri ile Kilis Tarihi, İstanbul 1968.

KUBAN, Doğan, Osmanlı Dini Mimarisinde İç Mekan Teşekkülü (Rönesansla Bir Mukayese), İstanbul 1958.

KURAN, Aptullah, Mimar Sinan, Ankara 1987.

MEINECKE, Michael, "Syrian Blue and White Tiles of the 9th/15th Century", Damaszener Mittellungen, 3, 1988, s. 203-214.

MÜLAYİM, Selçuk, “Kubbe”, Türkiye Diyanet Vakfı İslam Ansiklopedisi, C. 26, Ankara 2002, s. 300-303.

NECİPOĞLU, Gülru, Sinan Çağı Osmanlı İmparatorluğu'nda Mimarî Kültür, İstanbul 2013.

OKÇUOĞLU, Tarkan, Anadolu Selçuklu Mescitlerinde Kubbeye Geçiş Alanının Değerlendirilmesi, İstanbul Üniversitesi Sosyal Bilimler Enstitüsü, Sanat Tarihi Yüksek Lisans Tezi, İstanbul 1995.

OKÇUOĞLU, Tarkan, “Hadım İbrahim Paşa Camii”, Dünden Bugüne İstanbul Ansiklopedisi, C. 3, İstanbul 1994, s. 490-491.

ÖNKAL, Hakk1, Anadolu Selçuklu Türbeleri, İstanbul 2015.

RABY, J., "Diyarbakır, a Rival to İznik", İstanbuler Mittelungen, 27/28, Tübingen, 1977-78, s. 439-459.

SEÇGIN, Nuri, Tokat'taki Türk Mimari Eserleri, Mimar Sinan Üniversitesi Sosyal Bilimler Enstitüsü, Arkeoloji ve Sanat Tarihi Anabilim Dalı, Türk ve İslam Sanatları Programı, Yüksek Lisans Tezi, İstanbul 1993.

SÖZEN, Metin, Diyarbakır'da Türk Mimarisi, İstanbul 1971.

TANMAN, M. Baha, “Hekimoğlu Ali Paşa Camii’ne İlişkin Bazı Gözlemler”, Aslanapa Armağanı, İstanbul 1996, s. 253-280.

TEKIN, Kemal Hakan, Halep’teki Osmanlı Dönemi Dini Eserleri, Erciyes Üniversitesi Sosyal Bilimler Enstitüsü, İslam Tarihi ve Sanatları Anabilim Dalı Doktora Tezi, Kayseri 2008.

TUNCER, Orhan Cezmi, “Batıda Merkezi Kubbe ve Koca Sinan'ın Mekân Kavramı”, Sanat Tarihi Yıllığı, S. 12, İstanbul 1983, s. 149-160.

TUNCER, Orhan Cezmi, Diyarbakır Camileri Mukarnas Geometri Orantı, Diyarbakır 1996.

ULUÇAM, Abdüsselam, “Bağdad'da Abdülkadir Geylanî (K. S.) Külliyesi”, Vakıflar Dergisi, S. 20, Ankara 1988, s. 63-84.

ULUÇAM, Abdüsselam, Irak’taki Türk Mimari Eserleri, Ankara 1989.

UYSAL, Ali Osman, “Tokat’taki Osmanlı Camileri”, Türk Tarihinde ve Kültüründe Tokat Sempozyumu, Ankara 1987, s. 313-364. 
YAZICI, Yalçın, Tokat’ta Osmanlı Devri Mimari Eserleri, İstanbul Üniversitesi Edebiyat Fakültesi Türk İslam Sanatı Kürsüsü Lisans Tezi, İstanbul 1966.

YENIŞEHIRLIOĞLU, Filiz, "Les Revetement de Ceramiques Dans Les Edifices Ottomans de Diyarbakır au XVI e Siecle”, Ars Turcica, Akten des VI. Inetrnalen Kongresses für Türksche Kunst, Münih 1987, s. 368-393.

YETKİN, Suut Kemal, "Beylikler Devri Mimarisinin Klasik Osmanlı Sanatını Hazırlayışı”, Ankara Üniversitesi İlahiyat Fakültesi Dergisi, C. 4, S. 3, Ankara 1955, s. 39-43.

YETKIN, Şerare, “İstanbul Silivrikapı'daki Hadım İbrahim Paşa Camii’nin Çinilerindeki Özellikler”, Sanat Tarihi Yıllığı, S. 13, İstanbul 1988, s. 199-211.

YÜKSEL, Aydın, Osmanlı Mimarisi: II. Bayezıd, Yavuz Selim Devri, İstanbul 1983.

YÜKSEL, İ. Aydın, Osmanlı Mimarisinde Kânûnî Sultan Süleyman Devri (926-974/15201566) İstanbul, C. VI, Ankara 2004. 